\title{
Implications of structural diversity for seasonal and annual carbon dioxide fluxes in two temperate deciduous forests
}

Tamrakar, Rijan; Rayment, Mark B.; Moyano, Fernando; Mund, Martina; Knohl, Alexander

\section{Agricultural and Forest Meteorology}

DOI:

10.1016/j.agrformet.2018.08.027

Published: 15/12/2018

Peer reviewed version

Cyswllt i'r cyhoeddiad / Link to publication

Dyfyniad o'r fersiwn a gyhoeddwyd / Citation for published version (APA):

Tamrakar, R., Rayment, M. B., Moyano, F., Mund, M., \& Knohl, A. (2018). Implications of structural diversity for seasonal and annual carbon dioxide fluxes in two temperate deciduous forests. Agricultural and Forest Meteorology, 263, 465-476.

https://doi.org/10.1016/j.agrformet.2018.08.027

\footnotetext{
Hawliau Cyffredinol / General rights

Copyright and moral rights for the publications made accessible in the public portal are retained by the authors and/or other copyright owners and it is a condition of accessing publications that users recognise and abide by the legal requirements associated with these rights.

- Users may download and print one copy of any publication from the public portal for the purpose of private study or research.

- You may not further distribute the material or use it for any profit-making activity or commercial gain

- You may freely distribute the URL identifying the publication in the public portal ?
}

Take down policy

If you believe that this document breaches copyright please contact us providing details, and we will remove access to the work immediately and investigate your claim. 


\section{Abstract}

2 The effects of structural diversity on the carbon dioxide exchange $\left(\mathrm{CO}_{2}\right)$ of forests has

3 become an important area of research for improving the predictability of future $\mathrm{CO}_{2}$

4 budgets. We report the results of a paired eddy covariance tower experiment with 11

5 years of data on two forest sites of similar mean stand age, near-identical site conditions,

6 and dominated by beech trees (Fagus sylvatica), but with a very different stand structure

7 (incl. age, diameter distribution, stocks of dead wood and species composition) because

8 of different management regimes. Here we address the question of how management and

9 related structural diversity may affect $\mathrm{CO}_{2}$ fluxes, and tested the hypothesis that more structurally diverse stands are less sensitive to variations in environmental and biotic

11 drivers. Higher annual net ecosystem productivity (NEP) was observed in the

12 homogenous, managed, and even-aged forest $\left(585 \pm 57.8 \mathrm{~g} \mathrm{C} \mathrm{m}^{-2} \mathrm{yr}^{-1}\right)$, than in the

13 structurally diverse, unmanaged, and uneven-aged forest $\left(487 \pm 144 \mathrm{~g} \mathrm{C} \mathrm{m}^{-2} \mathrm{yr}^{-1}\right)$. About two-third of the difference in NEP between the sites was contributed by a higher annual gross primary productivity (GPP, $1627 \pm 164 \mathrm{vs} 1558 \pm 118 \mathrm{~g} \mathrm{C} \mathrm{m}^{-2} \mathrm{yr}^{-1}$ ) and one-third by a lower annual ecosystem respiration (Reco, $1042 \pm 60$ vs $1071 \pm 96 \mathrm{~g} \mathrm{C} \mathrm{m}^{-2} \mathrm{yr}^{-1}$ ) in

17 the homogenous forest. Spring (April - May) and summer (June - July) were the two main seasons contributing to the overall annual differences between the sites, also, the sensitivities of seasonal NEP and GPP to environmental variables were stronger in the homogenous forest during those periods. Inter-annual variation of NEP was higher in the

21 homogenous forest (Coefficient of variation $(\mathrm{CV})=25 \%$ ) compared to the

22 heterogeneous forest $(\mathrm{CV}=12 \%)$. At annual time scale, the higher variability of NEP in 23 the homogenous forest is mainly attributed to biotic factors such fruit production and a 24 time-dependent growth trend, outweighing differences in environmental sensitivities.

25 Keywords: structural diversity; eddy covariance; temperate deciduous forest; $\mathrm{CO}_{2}$ flux. 
27 The carbon uptake of forests is affected by changes in both environmental and biotic factors (Chen et al., 2015; Ciais et al., 2005). The former includes temperature, radiation, water and nutrient availability, and their intra and inter-annual variability. Biotic factors include plant functional traits such as plant physiological parameters, nutrient status, structure, phenology, etc., that govern photosynthesis and respiration process (Jensen et al., 2017) as well as inter- and intra-specific competition. Identifying and understanding the factors that contribute to the variability in net carbon dioxide $\left(\mathrm{CO}_{2}\right)$ uptake, i.e. net ecosystem productivity (NEP), between forest ecosystems and the atmosphere is crucial for understanding how forests will respond to and affect future climate (Baldocchi et al., 2001; IGBP Terrestrial Carbon Working Group, 1998; Luo et al., 2015) as well as for answering questions relevant to forest management and ecology.

Many eddy covariance (EC) flux studies (e.g. Barr et al., 2007; Dragoni et al., 2011; Hui et al., 2003; Humphreys and Lafleur, 2011; Jensen et al., 2017; Kitamura et al., 2012;

Richardson et al., 2009; Shao et al., 2016, 2015; Wu et al., 2013; Yuan et al., 2009) have attributed the inter-annual variability (IAV) of NEP variously to climatic variables, to phenological changes induced by climatic variables and to biotic changes, with Richardson et al. (2007) contending that, on an annual scale, variation in NEP is more strongly dominated by changes in biotic factors than by climate. To date, most studies have focused on understanding effects of climate and biotic changes on $\mathrm{CO}_{2}$ fluxes at single sites (Granier et al., 2008; Pilegaard et al., 2011; Wilkinson et al., 2012) or across contrasting ecosystem types (Baldocchi and Xu, 2005; Chu et al., 2016; Jensen et al., 2017; Ma et al., 2007; Novick et al., 2015; Pereira et al., 2007; Shao et al., 2016, 2015, 2014; Wu et al., 2012). Other studies have used multiple sites from across global and regional networks to understand the variability of $\mathrm{CO}_{2}$ fluxes from different plant

51 functional types and/or climatic zones (Beer et al., 2010; Chen et al., 2015; Law et al., 
2002; Musavi et al., 2017). Such studies have been beneficial for understanding the underlying causes of variability in $\mathrm{CO}_{2}$ uptake, but because flux stations are not closely located, there are typically very large differences in the environmental conditions between sites, making it challenging to disentangle the effects of environmental vs biotic factors. The short period of time analysed is also a limitation found in some studies (Anthoni et al., 2004; Hommeltenberg et al., 2014; Jensen et al., 2017). Only a few have investigated how structure and management scheme affect $\mathrm{CO}_{2}$ fluxes (Herbst et al., 2015; Musavi et al., 2017) even though it is reasonable to suppose that these are important drivers of $\mathrm{CO}_{2}$ fluxes and that they may interact with climate and biotic variables (Luyssaert, 2014).

Here we present a case study that, in contrast, focuses on two forest sites that a) are characterized by similar site conditions, b) have a similar mean age, and c) are both dominated by beech trees (Fagus sylvatica) but differ in management regime and structure. We thus tackle the question of how management and related structural diversity may affect $\mathrm{CO}_{2}$ fluxes, and directly test the hypothesis that more structurally diverse stands are less sensitive to variations in environmental and biotic drivers. This study builds on the work of Herbst et al. (2015), which was done at the same sites and showed their difference in carbon uptake and water use.

We seek to identify the major drivers of seasonal and inter-annual variability of net ecosystem productivity (NEP), gross primary productivity (GPP) and ecosystem respiration (Reco) of a structurally-diverse and a structurally-homogeneous temperate broadleaf forest. We test two hypotheses:

(1) The annual NEP and GPP of the homogeneous forest is more sensitive to variation in climate variables compared to the heterogeneous forest. A study utilizing tree rings has shown that productivity of diverse temperate beech forests exhibited higher temporal stability than monoculture forests mainly due to lower inter-annual variation as well as 
$902 . \quad$ Materials and methods among the interacting species.

1. Site description

due to overyielding because of asynchronous behaviour of different tree species and their interactions (Jucker et al., 2014). Grossiord et al. (2014) observed higher water availability in mixed temperate beech forests than in single species forests during drought, which they speculate as result of niche partitioning and/or facilitation processes

(2) NEP and GPP of the homogeneous forest is more sensitive to intrinsic speciesdetermined characteristics such as fruit production. Synchronous fruit production, also known as masting, is a sink for plant resources that may compete with vegetative growth (Obeso, 2002) and a negative correlation between fruit production and radial stem increment has been observed (Dittmar et al., 2003; Selås et al., 2002). Herbst et al. (2015) reported higher fruit production in the homogenous forest and here we will also quantify the effect of fruit production on annual NEP and GPP.

2 Data were obtained from two forest sites, Hainich (DE-Hai) and Leinefelde (DE-Lnf),

3 located in central Germany (Figure 1). The two sites are ca. $30 \mathrm{~km}$ apart both at an

4 altitude of 450 mean above sea level. Soil at both sites is composed of Triassic limestone covered with variable Pleistocene loess deposits. The climate is suboceanic-submontane with a long-term annual mean air temperature of ca. $8{ }^{\circ} \mathrm{C}$. General site characteristics are 7 given in Table 1. The phenology of both sites is similar, with the dormant season lasting 8 typically from November to March and growing season lasting from April to October. 


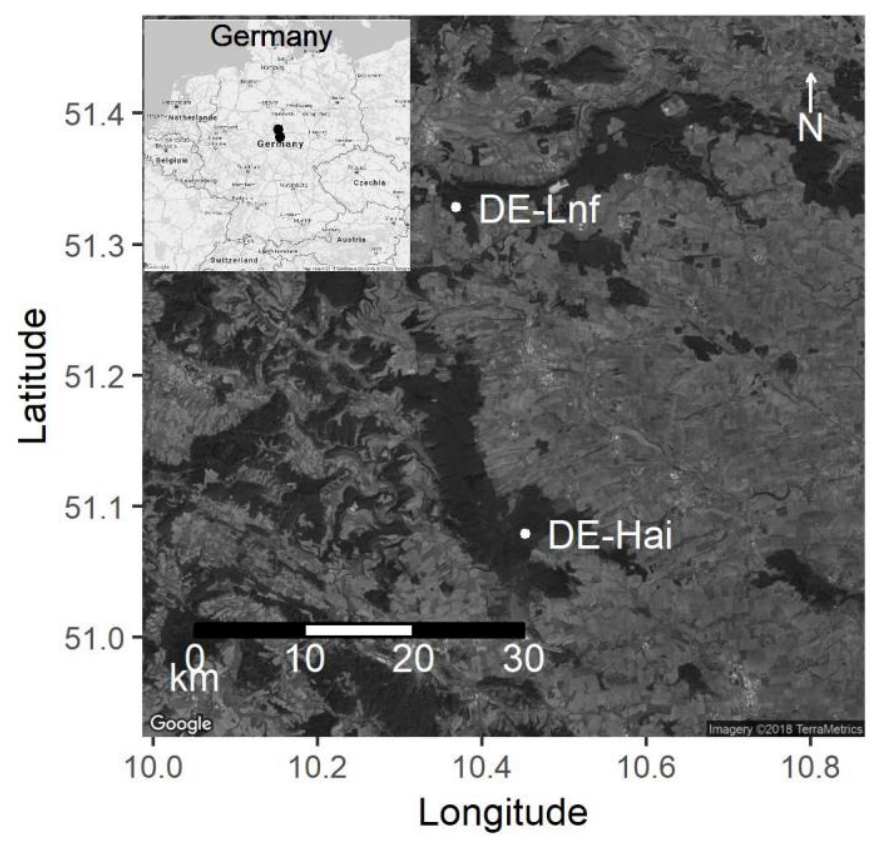

Figure 1: Map showing the location of the two study sites in the central Germany. Darker patches are forests and white dots show the positions of the eddy covariance flux towers 102 at each site. Map of Germany in inset is not to scale.

103 Hainich: The Hainich site (DE-Hai) is an unmanaged forest with a heterogeneous

105 Table 1: Instrumentation and stand characteristics for the research sites.

\begin{tabular}{|c|c|}
\hline Characteristics & Hainich (DE-Hai) \\
\hline Latitude & $51^{\circ} 04^{\prime} 45,36^{\prime \prime} \mathrm{N}$ \\
\hline Longitude & $10^{\circ} 27^{\prime} 07,20^{\prime \prime} \mathrm{E}$ \\
\hline Altitude [m] & 440 \\
\hline Soil & $\begin{array}{l}\text { Pleistocene loess deposits with dominance of } \\
\text { Cambisols }\end{array}$ \\
\hline \multicolumn{2}{|l|}{ Instrumentation } \\
\hline EC measuring height $[\mathrm{m}]$ & 44 \\
\hline Displacement height [m] & 22 \\
\hline Sonic anemometer & Gill Sonic Model R3 \\
\hline Infra-red gas analyser (IRGA) & Li6262 \\
\hline \multicolumn{2}{|l|}{ Stand characteristics } \\
\hline Primary species & $\begin{array}{l}\text { Fagus sylvatica } \mathrm{L}(64 \%) \text {., Fraxinus excelsior } \mathrm{L} \text {. } \\
(28 \%) \text {, Acer pseudoplatanus } \mathrm{L}(7 \%) \text {. and other } \\
\text { species }\end{array}$ \\
\hline Biomass [t C ha ha $^{-1}$ & 212 \\
\hline Plant density [trees ha $\left.{ }^{-1}\right]$ & 334 \\
\hline Canopy height $[\mathrm{m}]$ & 35 \\
\hline $\operatorname{LAI}\left[\mathrm{m}^{2} \mathrm{~m}^{-2}\right]$ & 5.1 \\
\hline Age (years) & $\begin{array}{l}\text { Maximum up to } 265 \text {, } \\
\text { biomass weighted average }=140\end{array}$ \\
\hline
\end{tabular}

106 found in Anthoni et al. (2004) and Knohl et al. (2003). Until the end of the $19^{\text {th }}$ century, it

107 was managed as a coppice-with-standards system and was subjected to selective cutting

108 until 1965. From 1965 to 1997, the area was used as a military training base and a large

109 part of the forest was left untouched, with only single and very valuable trees being cut.

110 The forest has never been clear felled and, as a result, it exhibits characteristics of an 
unmanaged, old-growth forest with highly diverse horizontal and vertical structure, trees covering a wide range of age classes, up to a maximum of around 265 years, and large amounts of dead wood (both standing dead wood and coarse woody debris). The main

114

tree species in the forest are beech (Fagus sylvatica, ca. 64\% of tree biomass), ash (Fraxinus excelsior, ca. 28\%), and sycamore (Acer pseudoplatanus, ca. 7\%), with some single trees of European hornbean (Carpinus betulus), elm (Ulmus glabra), maple (Acer platanoides) and other deciduous species. The main ground vegetation in the forest includes Allium ursinum, Mercurialis perennis and Anemone nemorosa (Mund, 2004). The Hainich flux tower site is located on a gentle north facing slope ( $2-3^{\circ}$ inclination) surrounded by forest for more than $3 \mathrm{~km}$ in the prevailing wind direction. The only change in the surface land use is a small clearing located about $800 \mathrm{~m}$ perpendicular to the prevailing wind, with only $5 \%$ contribution to the overall wind direction (Knohl et al., 2003).

Leinefelde: The Leinefelde site (DE-Lnf) is an even-aged, pure beech stand managed as a shelterwood system for maximum wood production since 1938. DE-Lnf is an example of a homogenous managed even-aged $130 \pm 8$ years old stand that represents a late point in time of a rotation period (production cycle) lasting about 120-140 years. Crown thinning - thinning of dominant trees to reduce crowding within the main canopy - is carried out in different forest blocks regularly every 10-20 years. The last major thinning in the footprint area of the flux tower was carried out from 2002 to 2006 (Figure S1). The ground vegetation includes Galium odoratum, Melica nutans, Milium effusum, Oxalis acetosella, and Stellaria holostea. The eddy covariance flux tower has been in operation since April 2002. No measurements were carried out in this site from 2007 to 2009 due to access limitation.

2. Eddy covariance and meteorological measurements 
136 Fluxes of carbon dioxide, water vapor, sensible heat, and momentum along with standard

137 meteorological variables were measured at the two study sites. The two sites had identical

138 eddy covariance instrumental setup and data acquisition techniques. The eddy covariance

139 measurement system consisted of a three-dimensional sonic anemometer (Solent R3, Gill

140 Instruments Ltd., Lymington, UK) and a fast response closed-path $\mathrm{CO}_{2} / \mathrm{H}_{2} \mathrm{O}$ infrared gas

141 analyser in absolute mode (LI-6262, LI-COR Inc., Lincoln, NE, USA). The tube

142 connecting the gas inlet and gas analyser was $50 \mathrm{~m}$. Data were collected on a field

143 computer using the "EddySoft" software developed by O. Kolle from MPI-

144 Biogeochemistry, Jena, Germany (Kolle and Rebmann, 2010). Detailed information

145 about the instrumentation can be found in Anthoni et al. (2004); Knohl et al. (2003). The

146 turbulent fluxes were calculated using "EddyPro" software with same settings for both

147 sites and all years. We followed Aubinet et al. (1999) and Foken et al. (2004) for quality

148 control of the data collection and analyses. We used the "Fluxnet" online-tool

149 (http://www.bgc-jena.mpg.de/bgi/index.php/Services/REddyProcWeb) and the

150 REddyProc package in R (Wutzler et al., 2018) based on Reichstein et al. (2005) to

151 obtain a continuous dataset of net ecosystem exchange and for partitioning this into gross

152 primary production (GPP) and ecosystem respiration (Reco).

153 Standard meteorological data were measured at both the sites. Anthoni et al. (2004) and

154 Knohl et al. (2003) describe the details of the meteorological variables and

155 instrumentation.

156 We used the Biljou model to calculate a water availability index (WAI). Details of this

157 model are available in Granier et al. (1999).

$158 \quad 3 . \quad$ Fruit production data

159 Periodical fruit production is an important characteristic of beech forests. In this study,

160 we included fruit production as a biotic variable that is assumed to affect annual carbon

161 fluxes. The fruits (seed and pericarp) were collected in litter traps (DE-Hai 25, DE-Lnf 21 
162

163

164

165

traps of $0.25 \mathrm{~m}^{2}$ ) distributed within the main footprint, dried at $70^{\circ} \mathrm{C}$ and weighed. The traps are closed plastic funnels with a small sieve at the bottom for retaining fruits while allowing drainage. The funnels are fixed on a pillar about $50 \mathrm{~cm}$ above the ground so that herbivores (mostly mice) are kept out.

\section{Statistical analysis}

Data from April 2002 to 2006 and from 2010 to 2016, the period with complete flux and meteorological data, was used to investigate the effect of meteorological variables on seasonal fluxes. We calculated zero-order correlations and slopes of the simple linear regressions between seasonal fluxes and meteorological variables. We also tested the differences of the sensitivities of seasonal $\mathrm{CO}_{2}$ fluxes to meteorological variables between sites (Lenth and Love, 2017).

At annual scale, we used data from 2003 to 2006 and 2010 to 2016 (no fruit production data was available for 2002). Paired T-tests were applied to test for significant differences in annual $\mathrm{CO}_{2}$ fluxes and meteorological variables between the sites. For selecting which predictor explained annual NEP, GPP and Reco, we conducted stepwise multiple linear regression (MLR) using the Akaike Information Criteria (AIC) (Field et al., 2012). The predictor variables considered for the study were mean annual air temperature $\left(\mathrm{T}_{\text {air }}\right)$, soil temperature $\left(\mathrm{T}_{\text {soil }}\right)$, global radiation $\left(\mathrm{R}_{\mathrm{g}}\right)$, vapor pressure deficit $(\mathrm{VPD})$, water availability index (WAI), spring air temperature, spring soil temperature, fruit production, growing season length, and time. The variable time was represented by calendar year. Thus, it integrates the effects of factors that vary and correlate with time, such as growth, effects of $\mathrm{CO}_{2}$ fertilization (Fernández-Martínez et al., 2017), phenology (Baldocchi et al., 2018; Froelich et al., 2015; Granier et al., 2008; Pilegaard et al., 2011; Urbanski et al., 2007), and changes in nutrient deposition (Fernández-Martínez et al., 2017). To create a model applicable to both sites, we defined a MLR model using all the variables selected as significant during the per-site fits and fitted it again, this time to the combined data from 
both sites. To estimate the relative effects of model predictor variables on response

189 variables, we calculated the 'product measure' which distributes the overall model $\mathrm{R}^{2}$ to each of the predictors (Nathans et al., 2012). Product measure is the product of a residuals, i.e. after having removed the effects of other predictor variables via multiple

194 linear regression. R version 3.4.3 was used for analyses (R Core Team, 2017).

1. Meteorological characteristics

197 The two sites were meteorologically similar (Figure 2). Averaged yearly global radiation $198\left(\mathrm{R}_{\mathrm{g}}\right.$ ) from 2002 to 2016 was $122.4 \pm 6.5 \mathrm{~W} \mathrm{~m}^{-2}$ (mean $\pm \mathrm{sd}$ ) in DE-Hai and 124.0 $\pm 7.2 \mathrm{~W}$ $199 \mathrm{~m}^{-2}$ in DE-Lnf (Figure 2a). Mean annual temperature $\left(\mathrm{T}_{\text {air }}\right)$ during the study period was $2008.34 \pm 0.72{ }^{\circ} \mathrm{C}$ and $8.30 \pm 0.7^{\circ} \mathrm{C}$ for DE-Hai and DE-Lnf, respectively. This similarity was consistent for all years with no statistically significant differences between the sites. The mean annual soil temperature $\left(\mathrm{T}_{\text {soil }}\right)$ was $7.61 \pm 0.36{ }^{\circ} \mathrm{C}$ and $8.23 \pm 0.38{ }^{\circ} \mathrm{C}$ for DE-

203 Hai and DE-Lnf, respectively. A systematically higher value of $0.62{ }^{\circ} \mathrm{C}$ was measured in 204 DE-Lnf $(\mathrm{p}<0.001)$, possibly resulting from differences in the measurement depth 205 between the sites (5 vs $4 \mathrm{~cm}$ in DE-Hai and DE-Lnf, respectively, Figure S2). Mean 206 annual vapor pressure deficit (VPD) was $3.45 \pm 0.56 \mathrm{hPa}$ and $3.28 \pm 0.41 \mathrm{hPa}$ at DE-Hai 207 and DE-Lnf, respectively, with no statistical difference between the sites. Mean annual 208 precipitation - based on a single pluviometer per site - was significantly lower ( $<$ 209 0.001) in DE-Lnf $(601 \pm 154 \mathrm{~mm})$ than in DE-Hai $(744 \pm 152 \mathrm{~mm})$. Although DE-Lnf 210 received less rainfall, the mean annual water availability index (WAI) was similar 211 between the sites in most years, with average values of 0.86 and 0.84 in DE-Hai and DE- 
213 (Table S1).

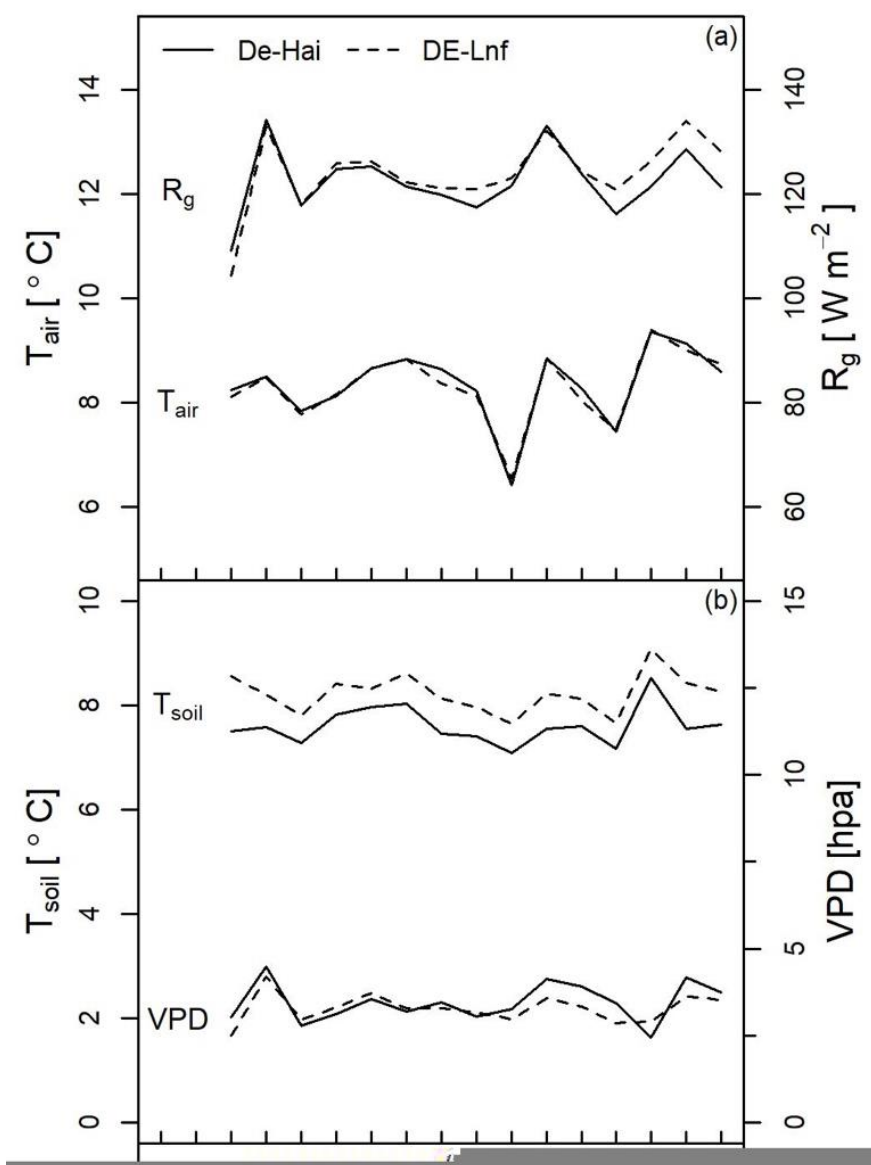

215 Figure 2: Mean annual values of (a) global radiation $\left(\mathrm{R}_{\mathrm{g}}\right)$ and air temperature $\left(\mathrm{T}_{\mathrm{air}}\right)$; (b) 216 soil temperature $\left(\mathrm{T}_{\text {soil }}\right)$ and vapor pressure deficit (VPD); and (c) water availability index 217 (WAI) and rainfall are shown from 2002 to 2016. $\mathrm{T}_{\text {soil }}$ was measured at $5 \mathrm{~cm}$ for DE-Hai 218 and $4 \mathrm{~cm}$ for DE-Lnf. 


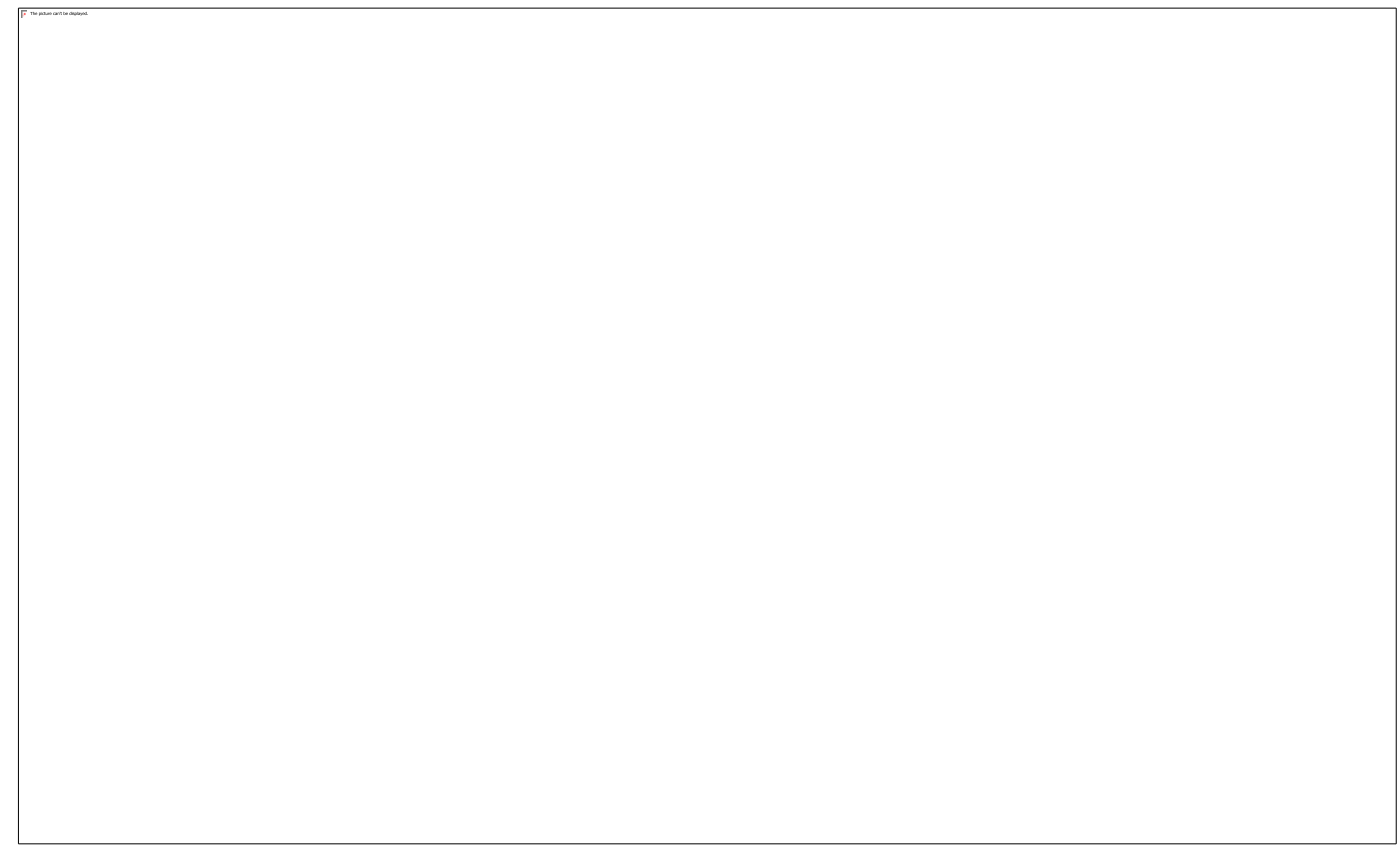

221 Figure 3: Total annual fruit production $\left(\mathrm{g} \mathrm{C} \mathrm{m}^{-2} \mathrm{yr}^{-1}\right)$ in DE-Hai and DE-Lnf from 1999 to 222 2016. No data was recorded in 2001 and 2002.

223 Figure 3 shows the fruit production (masting) data for DE-Hai and DE-Lnf from 1999 to

224 2016. Data for 2001 and 2002 was not available due to technical issues. The average fruit 225 production for the entire period was $73.2 \pm 77.9 \mathrm{~g} \mathrm{C} \mathrm{m}^{-2} \mathrm{yr}^{-1}$ and $91.2 \pm 113.1 \mathrm{~g} \mathrm{C} \mathrm{m}^{-2} \mathrm{yr}^{-1}$ 226 in DE-Hai and DE-Lnf, respectively. We define masting years as those when fruit 227 production is more than $50 \mathrm{~g} \mathrm{C} \mathrm{m}^{-2} \mathrm{yr}^{-1}$. Masting years occurred every two or three years. 228 Average fruit production during such years was $151 \pm 46.3 \mathrm{~g} \mathrm{C} \mathrm{m}^{-2} \mathrm{yr}^{-1}$ and $197 \pm 91.8 \mathrm{~g}$ $\mathrm{C} \mathrm{m}^{-2} \mathrm{yr}^{-1}$ for DE-Hai and DE-Lnf, respectively, with the former being $76 \%$ of the latter. The significant differences between DE-Lnf und DE-Hai are restricted to the extraordinarily high mast years (fruit production $>200 \mathrm{~g} \mathrm{C} \mathrm{m}^{-2}$ ).

3. Cumulative net ecosystem productivity (NEP)

233 Figure 4 shows gap-filled cumulative net ecosystem productivity (NEP) data calculated

234 from eddy covariance measurements of $\mathrm{CO}_{2}$ fluxes. Positive values correspond to a

235 cumulative net uptake of $\mathrm{CO}_{2}$ by the vegetation (atmospheric sink) and negative values a 236 net loss (atmospheric source). At the beginning of each year, both forests are sources of $237 \mathrm{CO}_{2}$. The average day of the year (doy) at which the net daily NEP switches from source 
to sink (i.e. shortly after leaf-out when the rate of change in the cumulative NEP goes

239 from negative to positive) was 125 and 121 for DE-Hai and DE-Lnf, respectively (

240 Table S2). But this was observed as early as doy 111 in DE-Hai and 112 in DE-Lnf in

241 2014, and as late as doy 134 in DE-Hai in 2010 and doy 130 in DE-Lnf in 2013. The

242 forests continued to act as an overall $\mathrm{C}$ sink in average for 164 days and 168 days for DE-

243 Hai and DE-Lnf, respectively. This growing season length was significantly correlated

244 with mean annual temperature (Figure S3). Longer growing season length and earlier

245 start of growing season corresponded to higher annual carbon fluxes (Figure S4c, f, i).

246 Most of the variation in annual cumulative NEP occurred between the period of leaf out

247 and leaf fall. The inter-annual variability in NEP during the growing season was larger in

248 DE-Lnf compared to DE-Hai. On average, NEP in masting years was lower than in other 249 years, with this difference being particularly visible in DE-Lnf (black solid lines in Figure

4b). The lowest cumulative NEP for both sites was measured in 2004, a year characterized

251 by high fruit production but not the highest value observed during the study period.

Figure 4: Cumulative net ecosystem productivity for (a) DE-Hai and (b) DE-Lnf. The vertical grey bars indicate the time of leaf out and leaf fall. The positive values of NEP indicate a cumulative carbon uptake by the ecosystem.

4. Seasonal variability of the $\mathrm{CO}_{2}$ fluxes 
258 Both sites have a similar average annual cycle of NEP (Figure 5a). Each point corresponds

259 to the mean across years of weekly sums of NEP. Both forests reached the highest carbon

260 uptake rate between doy 165 and 175. DE-Lnf showed a higher positive NEP at the start of

261 the growing season, and DE-Hai was a stronger carbon source (black solid lines in Figure

262 5a) from November to December.

Figure 5: (a) The average annual NEP cycle, bar represents 95\% confidence interval at $2655 \%$ significance level and (b) standard deviation of weekly NEP. The grey horizontal bars 266 show the range of the leaf out and leaf fall days of the two sites.

267 Figure $5 \mathrm{~b}$ shows the standard deviation of weekly NEP across years. The standard

268 deviation of the early weeks of the year was low at both sites, and increased with the start

269 of the growing season. A higher standard deviation in NEP was observed in DE-Lnf

270 (dashed lines in Figure 5b) over the entire growing season. In DE-Hai (black solid lines

271 in Figure 5b), the highest standard deviation was observed between doy 215 and 230. 
272 During the last days of the year, DE-Hai exhibited a higher standard deviation compared

273 to DE-Lnf. For further analysis, we separated the year into different seasons, winter

274 months (November - December: ND, January - March: JFM), spring (April - May:

275 AM), summer (June- July: JJ), August (A) and fall (September - October: SO), to

276 account for the different drivers and dynamcs of NEP in these periods. August was

277 treated separately from the main growing season as it is a particularly dry month and

278 large variability observed in this period (see Figure 5b and Table 2).

280 For each site, Table 2 (correlation coefficients) and Figure 6 (absolute slopes) show the

281 effect of measured meteorological factors on $\mathrm{CO}_{2}$ fluxes for different seasons of the year

282 (see section 4).

283 Table 2: Zero-order correlation coefficients between seasonal carbon fluxes (NEP, GPP 284 and Reco) and meteorological variables (mean of monthly values) for JFM (January 285 March), AM (April - May), JJ (June- July), A (August), SO (September - October) and 286 ND (November - December) in DE-Hai and DE-Lnf. Bold numbers are statistical 287 significant values at $\mathrm{p}<0.05$.

\begin{tabular}{|c|c|c|c|c|c|c|c|c|c|c|c|c|c|c|c|c|}
\hline \multirow{2}{*}{ Season } & \multirow{2}{*}{ site } & \multicolumn{3}{|c|}{$\mathrm{T}_{\text {air }}$} & \multicolumn{3}{|c|}{$\mathrm{T}_{\text {soil }}$} & \multicolumn{3}{|c|}{$\mathrm{R}_{\mathrm{g}}$} & \multicolumn{3}{|c|}{ VPD } & \multicolumn{3}{|c|}{ WAI } \\
\hline & & NEP & GPP & Reco & NEP & GPP & Reco & NEP & GPP & Reco & NEP & GPP & Reco & NEP & GPP & Reco \\
\hline \multirow{2}{*}{ JFM } & DE-Hai & -0.51 & & 0.45 & -0.52 & & 0.58 & -0.45 & & 0.34 & -0.55 & & 0.41 & & & \\
\hline & DE-Lnf & -0.57 & & 0.78 & -0.49 & & 0.71 & -0.47 & & 0.6 & -0.66 & & 0.8 & & & \\
\hline \multirow{2}{*}{$\mathrm{AM}$} & DE-Hai & 0.85 & 0.88 & 0.82 & 0.87 & 0.91 & 0.85 & 0.6 & 0.53 & 0.34 & 0.42 & 0.33 & 0.12 & & & \\
\hline & DE-Lnf & 0.8 & 0.85 & 0.82 & 0.84 & 0.9 & 0.87 & 0.63 & 0.59 & 0.38 & 0.37 & 0.35 & 0.23 & & & \\
\hline \multirow{2}{*}{ JJ } & DE-Hai & 0.22 & 0.38 & 0.34 & 0.27 & 0.25 & 0.1 & 0.27 & 0.51 & 0.48 & 0.11 & 0.32 & 0.36 & 0 & -0.07 & -0.1 \\
\hline & DE-Lnf & 0.11 & 0.24 & 0.37 & -0.15 & -0.04 & 0.2 & 0.57 & 0.54 & 0.21 & 0.16 & 0.23 & 0.24 & -0.1 & 0 & 0.18 \\
\hline \multirow{2}{*}{ A } & DE-Hai & -0.36 & -0.27 & -0.02 & -0.36 & -0.24 & 0.06 & -0.38 & -0.33 & -0.15 & -0.5 & -0.49 & -0.35 & 0.65 & 0.68 & 0.54 \\
\hline & DE-Lnf & -0.27 & -0.24 & 0.06 & -0.41 & -0.34 & 0.13 & -0.17 & -0.17 & -0.02 & -0.23 & -0.35 & -0.3 & 0.08 & 0.37 & 0.65 \\
\hline \multirow{2}{*}{ SO } & DE-Hai & 0.75 & 0.83 & 0.74 & 0.79 & 0.86 & 0.73 & 0.87 & 0.88 & 0.55 & 0.65 & 0.69 & 0.53 & -0.32 & -0.33 & -0.23 \\
\hline & DE-Lnf & 0.62 & 0.7 & 0.81 & 0.7 & 0.77 & 0.86 & 0.76 & 0.8 & 0.75 & 0.46 & 0.52 & 0.59 & -0.19 & -0.18 & -0.12 \\
\hline \multirow{2}{*}{ ND } & DE-Hai & -0.76 & & 0.79 & -0.75 & & 0.74 & -0.78 & & 0.79 & -0.67 & & 0.76 & & & \\
\hline & DE-Lnf & -0.69 & & 0.75 & -0.72 & & 0.76 & -0.61 & & 0.64 & -0.52 & & 0.63 & & & \\
\hline
\end{tabular}


In winter, NEP was correlated with $\mathrm{T}_{\text {air }}, \mathrm{T}_{\text {soil }}, \mathrm{R}_{\mathrm{g}}$, and VPD at both sites with stronger

289 correlation in ND than JFM (Table 2). In ND, NEP was significantly sensitive (higher 290 absolute slopes) to $\mathrm{T}_{\text {air }}, \mathrm{T}_{\text {soil }}$ and VPD in DE-Hai than in DE-Lnf (Figure 6).

291 With the arrival of spring (April - May, AM), $\mathrm{T}_{\text {soil }}$ became the most important factor 292 controlling spring NEP, GPP and $\mathrm{R}_{\text {eco }}$ in both sites, followed in importance by $\mathrm{T}_{\text {air }}$, and $293 \mathrm{R}_{\mathrm{g}}$. A $1{ }^{\circ} \mathrm{C}$ change in spring $\mathrm{T}_{\text {soil }}$ changed the NEP by $28.07 \pm 6.92$ and $38.74 \pm 11.19 \mathrm{~g} \mathrm{C}$ $294 \mathrm{~m}^{-2}$ month $^{-1}$ in DE-Hai and DE-Lnf, respectively. NEP was driven mainly by GPP, as 295 seen by comparing $\mathrm{B}_{\text {Tsoil } \& \text { GPP }}$ (slope between $\mathrm{T}_{\text {soil }}$ and GPP, Figure 6e) and $\mathrm{B}_{\text {Tsoil\&Reco }}$ 296 (slope between $\mathrm{T}_{\text {soil }}$ and Reco, Figure 6f) for this period. NEP and GPP of DE-Lnf was 297 more sensitive to $\mathrm{T}_{\text {soil }}$ than DE-Hai with significantly higher $\mathrm{B}_{\text {Tsoil\&NEP (Figure 6d) and }}$ $298 \mathrm{~B}_{\text {Tsoil\&GPP }}($ Figure 6e).

299 In summer (June - July, JJ), $\mathrm{R}_{\mathrm{g}}$ remained a significant factor while other relationships 300 weakened. In DE-Hai, $\mathrm{R}_{\mathrm{g}}$ showed a weak relationship with NEP but significantly 301 correlated with both GPP and Reco, while in DE-Lnf it was significantly correlated with 302 NEP and GPP. The sensitivity of NEP and GPP to $\mathrm{R}_{\mathrm{g}}$ was higher in DE-Lnf compared to 303 DE-Hai. A change in $1 \mathrm{~W} \mathrm{~m}^{-2}$ of $\mathrm{R}_{\mathrm{g}}$ increased NEP by $0.74 \pm 0.47(\mathrm{p}<0.01) \mathrm{g} \mathrm{C} \mathrm{m}^{-2}$ 304 month $^{-1}$ in DE-Lnf and about $0.23 \pm 0.37(\mathrm{p}=0.11) \mathrm{g} \mathrm{C} \mathrm{m}^{-2} \mathrm{month}^{-1}$ in DE-Hai and the 305 difference between the sites is significant $(\mathrm{p}<0.1)$.

306 In August (A), only the soil water availability index (WAI) correlated significantly with $307 \mathrm{CO}_{2}$ fluxes, specifically with NEP, GPP and $\mathrm{R}_{\text {eco }}$ in DE-Hai and only with Reco in DE308 Lnf.

309 In fall (September - October, $\mathrm{SO}$ ), $\mathrm{T}_{\text {air }}, \mathrm{T}_{\text {soil }}, \mathrm{R}_{\mathrm{g}}$ and VPD, again became significantly correlated with NEP, GPP and $\mathrm{R}_{\mathrm{eco}}$ in both sites, with high correlation values for the first 311 three and slightly lower ones for VPD. 


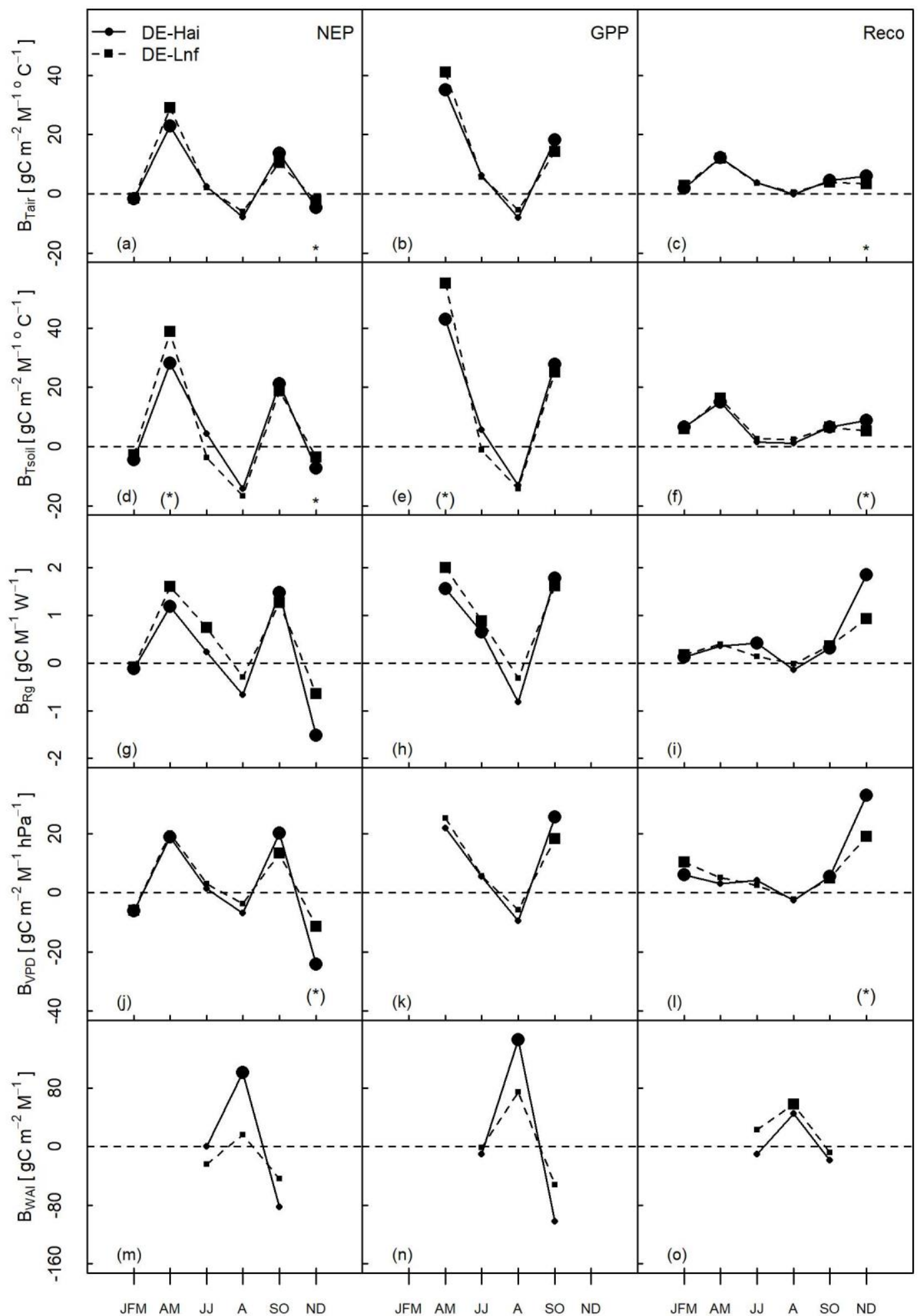

Figure 6: Slopes (B) between seasonal $\mathrm{CO}_{2}$ fluxes (NEP - column 1, GPP - column 2 and Reco - column 3) and meteorological variables (mean of monthly values) for JFM (January - March), AM (April - May), JJ (June- July), A (August), SO (September October) and ND (November - December). The larger circles and squares indicate slopes, which are significantly different from zero. $* * *$ indicate statistical significant difference of slopes between two sites at $\mathrm{p}<0.001$; ** significant at $\mathrm{p}<0.01$; * significant at $\mathrm{p}<0.05$; and $(*)$ significant at $\mathrm{p}<0.1$ at bottom of each figure (if any). The first letter of each month is used in the timescale.

6. Seasonal differences in $\mathrm{CO}_{2}$ fluxes between the two sites 
lower Reco in DE-Lnf (Figure 7c). DE-Lnf also acted as a stronger carbon sink in the spring (26 g C m${ }^{-2}$ month $^{-1}$ ) which was mostly due to higher GPP of $24 \mathrm{~g} \mathrm{C} \mathrm{m}^{-2}$ month $^{-1}$. In JJ, difference between NEP in two sites were insignificant because both GPP and Reco

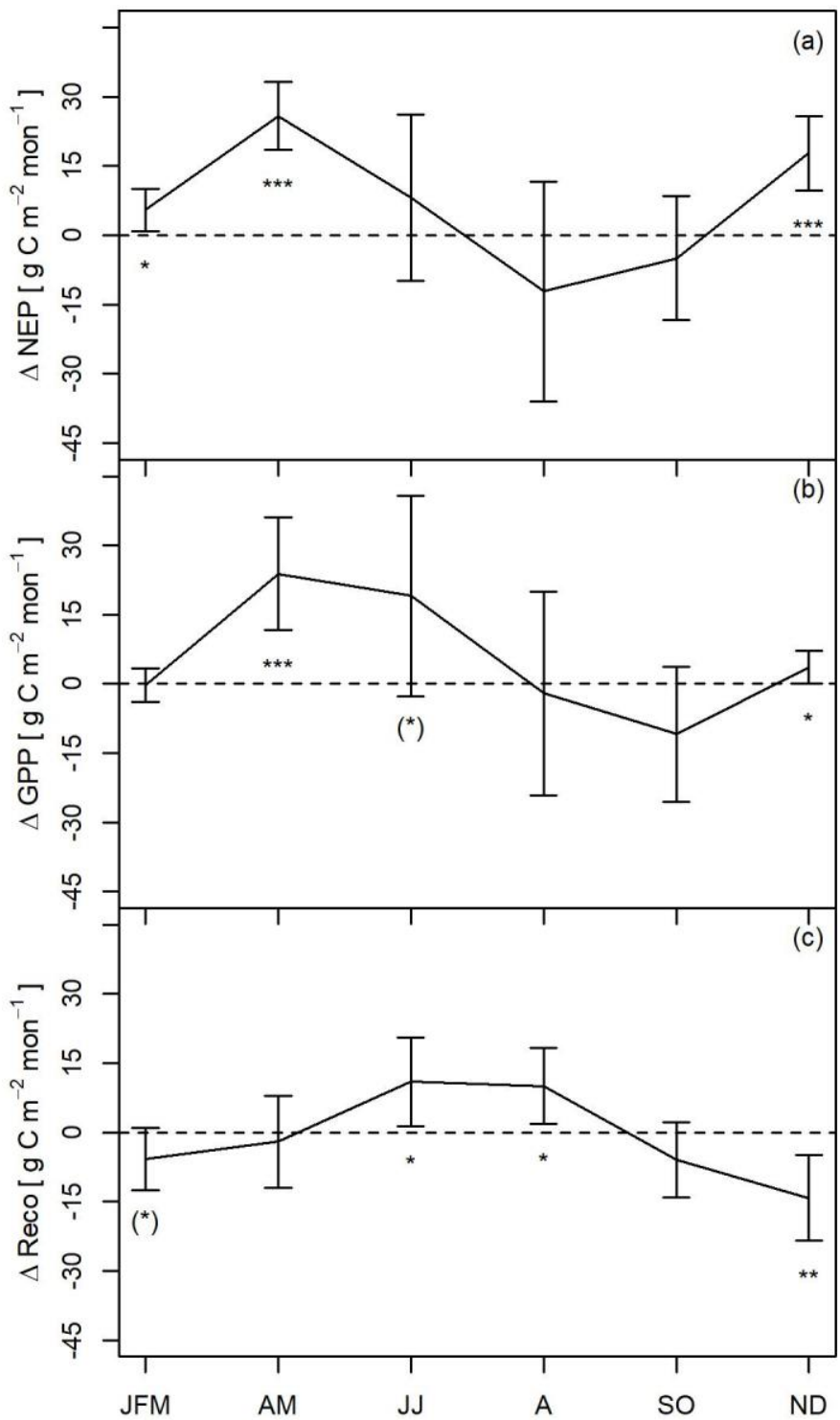

Figure 7: Difference in sum of (a) NEP, (b) GPP and (c) Reco between the two sites for JFM (January - March), AM (April - May), JJ (June- July), A (August), SO (September - October) and ND (November - December). The $\mathrm{Y}$-axis represents $\Delta \mathrm{X}=\mathrm{X}_{\mathrm{DE}-\mathrm{Lnf}}-\mathrm{X}_{\mathrm{DE}-}$ Hai (X being seasonal NEP, GPP or Reco). Bars represent 95\% confidence interval. The dashed line marks the zero line (indicates no difference between the sites). $* * *$ indicate statistical significance at $\mathrm{p}<0.001 ; * *$ significant at $\mathrm{p}<0.01 ;{ }^{*}$ significant at $\mathrm{p}<0.05$; and $(*)$ significant at $\mathrm{p}<0.1$.

In addition to slopes, we also looked at differences of average seasonal sums of NEP,

GPP and Reco between sites (Figure 7). Significantly higher NEPs observed in DE-Lnf than in DE-Hai in JFM and ND (5.48 and $17.79 \mathrm{~g} \mathrm{C} \mathrm{m}^{-2} \mathrm{month}^{-1}$, Figure 7a) was due to in DE-Lnf were significantly higher by $19.08 \mathrm{~g} \mathrm{C} \mathrm{m}^{-2}$ month $^{-1}$ and $10.94 \mathrm{~g} \mathrm{C} \mathrm{m}^{-2}$ month $^{-1}$, 
respectively. During August, NEP and GPP were similar in both sites, however, a higher Reco was observed in DE-Lnf $\left(10.04 \mathrm{~g} \mathrm{C} \mathrm{m}^{-2} \mathrm{month}^{-1}\right)$. In the fall, NEP, GPP and Reco were lower in DE-Lnf but differences were insignificant.

$$
\text { 7. Annual estimates of NEP, GPP and Reco }
$$

Annual gap-filled NEP, GPP and Reco for both sites are presented in Figure 8. Mean Annual NEP was $487 \pm 57.8$ (mean \pm SD for the mean of all years) and $585 \pm 144 \mathrm{~g} \mathrm{C} \mathrm{m}^{-}$ ${ }^{2} \mathrm{yr}^{-1}$ in DE-Hai and DE-Lnf, respectively. A paired t-test showed that DE-Lnf was a significantly stronger carbon sink $\left(98 \mathrm{~g} \mathrm{C} \mathrm{m}^{-2} \mathrm{yr}^{-1}, \mathrm{p}<0.05\right)$. We observed the largest differences in NEP between the two sites from 2010 (Table S3).

Annual NEP was significantly more variable in DE-Lnf (Levene's test with $\mathrm{p}<0.05$ ), with coefficients of variation (CV) being $12 \%$ and $25 \%$ in DE-Hai and DE-Lnf, respectively. A significant temporal trend of NEP was observed only for DE-Lnf, with an increase of $21.8 \mathrm{~g} \mathrm{C} \mathrm{m}^{-2} \mathrm{yr}^{-1}(\mathrm{p}<0.05)$.

The mean of annual GPP values at DE-Hai and DE-Lnf was $1559 \pm 118$ and $1627 \pm 164$ $\mathrm{g} \mathrm{C} \mathrm{m}^{-2} \mathrm{yr}^{-1}$ respectively, with the difference being statistically significant $(\mathrm{p}=0.07)$. Like NEP, significantly higher annual GPP was again observed in DE-Lnf from 2010 (Table S3). The variability in annual GPP was not significantly different between the two sites, with coefficients of variation (CV) equalling $7.5 \%$ and $10 \%$ in DE-Hai and DE-Lnf, respectively. As for annual NEP, no temporal trend in annual GPP was observed in DEHai, whereas a significant trend of $25.5 \mathrm{~g} \mathrm{C} \mathrm{m}^{-2} \mathrm{yr}^{-1}(\mathrm{p}<0.05)$ was observed in DE-Lnf. The mean annual ecosystem respiration (Reco) was $1071 \pm 96$ and $1042 \pm 60 \mathrm{~g} \mathrm{C} \mathrm{m}^{-2} \mathrm{yr}^{-1}$ in DE-Hai and DE-Lnf, respectively with no significant difference between sites. In contrast to annual NEP and GPP, annual Reco was lower in DE-Lnf with no significant difference. Annual Reco showed a positive temporal trend at both sites but it was statistically insignificant (Table S1). 


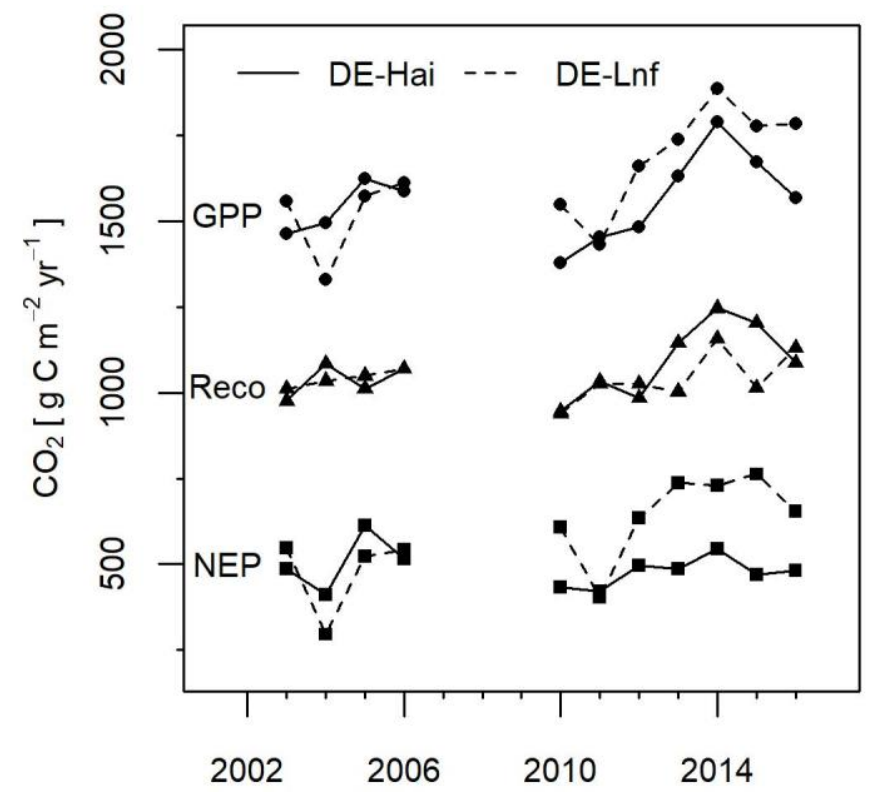

Figure 8: Annual sums of GPP, Reco and NEP from 2003 to 2016. Data from 2007 to 2009 was not measured in DE-Lnf.

8. Factors contributing to annual variability of NEP, GPP and Reco

Together, fruit production (FP), time (see the section 2.4) and mean annual soil temperature $\left(\mathrm{T}_{\text {soil }}\right)$ explained ca. $65 \%$ and $92 \%$ of the variation in annual NEP in DE-Hai and DE-Lnf, respectively (Table 3). In DE-Hai, $\mathrm{T}_{\text {soil }}$ was the most important factor, followed by FP (negative correlation). In the case of DE-Lnf, time and FP explained most of the variation.

371 Results were similar for annual GPP, with a total $\mathrm{R}^{2}$ of 0.62 and 0.88 in DE-Hai and DE372 Lnf, respectively. $\mathrm{T}_{\text {soil }}$ was the only significant variable for DE-Hai, explaining most of 373 the variation in GPP. In DE-Lnf, time was the strongest predictor variable, followed by $374 \mathrm{~T}_{\text {soil }}$ and FP (negative correlation). A significant relationship between annual Reco was 375 found only for DE-Lnf with $\mathrm{T}_{\text {soil }}$ as the only significant variable.

376 Figure 9 shows the relationship between each of the three significant driving variables 377 ( $\mathrm{T}_{\text {soil }}, \mathrm{FP}$, time) and the three flux quantities (NEP, GPP, Reco) in terms of the residual 378 variance remaining after the effects of the other two driving variables (e.g. FP and time, 379 in the case of $\mathrm{T}_{\text {soil }}$ ) have been removed. This analysis increased the amount of variation in 380 NEP and GPP explained by $\mathrm{T}_{\text {soil. }}$. We tested the difference between the slopes of two sites 381 obtained in Figure 9 (Table $\mathrm{S} 4$ ). The sensitivities of NEP on $\mathrm{T}_{\text {soil }}$ were similar between 
382 the sites when the effect of fruit production and time is removed. The result was similar 383 for GPP.

384 Similarly, fruit production was significantly correlated with residuals of NEP after

385 removing effect of $\mathrm{T}_{\text {soil }}$ and time (Figure 9b) in both sites. We observed that residuals of 386 GPP decreased with increased fruit production, but significant only for DE-Lnf and with

387 a more than twice as large slope (Figure 9e and Table S4). Slope between residuals of 388 annual Reco and fruit production was not significantly different from zero for both sites 389 but had a positive slope for DE-Lnf.

390 Only in DE-Lnf, we observed positive slope between time and residuals of NEP after

391 removing the effect of $\mathrm{T}_{\text {soil }}$ and FP (Figure 9c and Table S4). Higher slope of residuals of

392 Table 3: Major factors contributing to the variation of annual NEP, GPP and Reco. Var is 393 the contribution of each predictor to total $\mathrm{R}^{2}$ calculated with the product measure metric.

\begin{tabular}{|c|c|c|c|c|c|c|c|}
\hline \multirow[b]{2}{*}{ Flux } & \multirow[b]{2}{*}{ Predictors } & \multicolumn{3}{|c|}{ DE-Hai } & \multicolumn{3}{|c|}{ DE-Lnf } \\
\hline & & $\overline{\mathrm{R}^{2}}$ & Coefficients & Var & $\mathrm{R}^{2}$ & Coefficients & Var \\
\hline NEP & & 0.6 & & & 0.92 & & \\
\hline & $\mathrm{T}_{\text {soil }}+$ & & $110.48 *$ & 0.49 & & $79.94(*)$ & 0.07 \\
\hline & $\mathrm{FP}+$ & & $-0.34(*)$ & 0.15 & & $-0.74 * * *$ & 0.34 \\
\hline & Time & & -0.99 & 0.00 & & $22.30 * * *$ & 0.51 \\
\hline
\end{tabular}

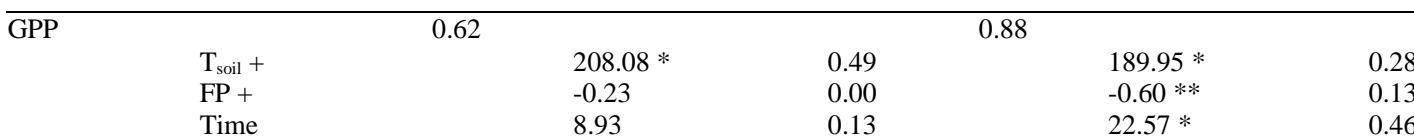

\begin{tabular}{|c|c|c|c|c|c|}
\hline \multirow[t]{4}{*}{ Reco } & \multicolumn{2}{|c|}{0.45} & \multicolumn{2}{|c|}{0.79} & \\
\hline & $\mathrm{T}_{\text {soil }}+$ & 97.61 & 0.19 & $109.90 * *$ & 0.65 \\
\hline & $\mathrm{FP}+$ & 0.02 & 0.00 & 0.14 & 0.14 \\
\hline & Time & 9.92 & 0.25 & 0.27 & 0.00 \\
\hline
\end{tabular}




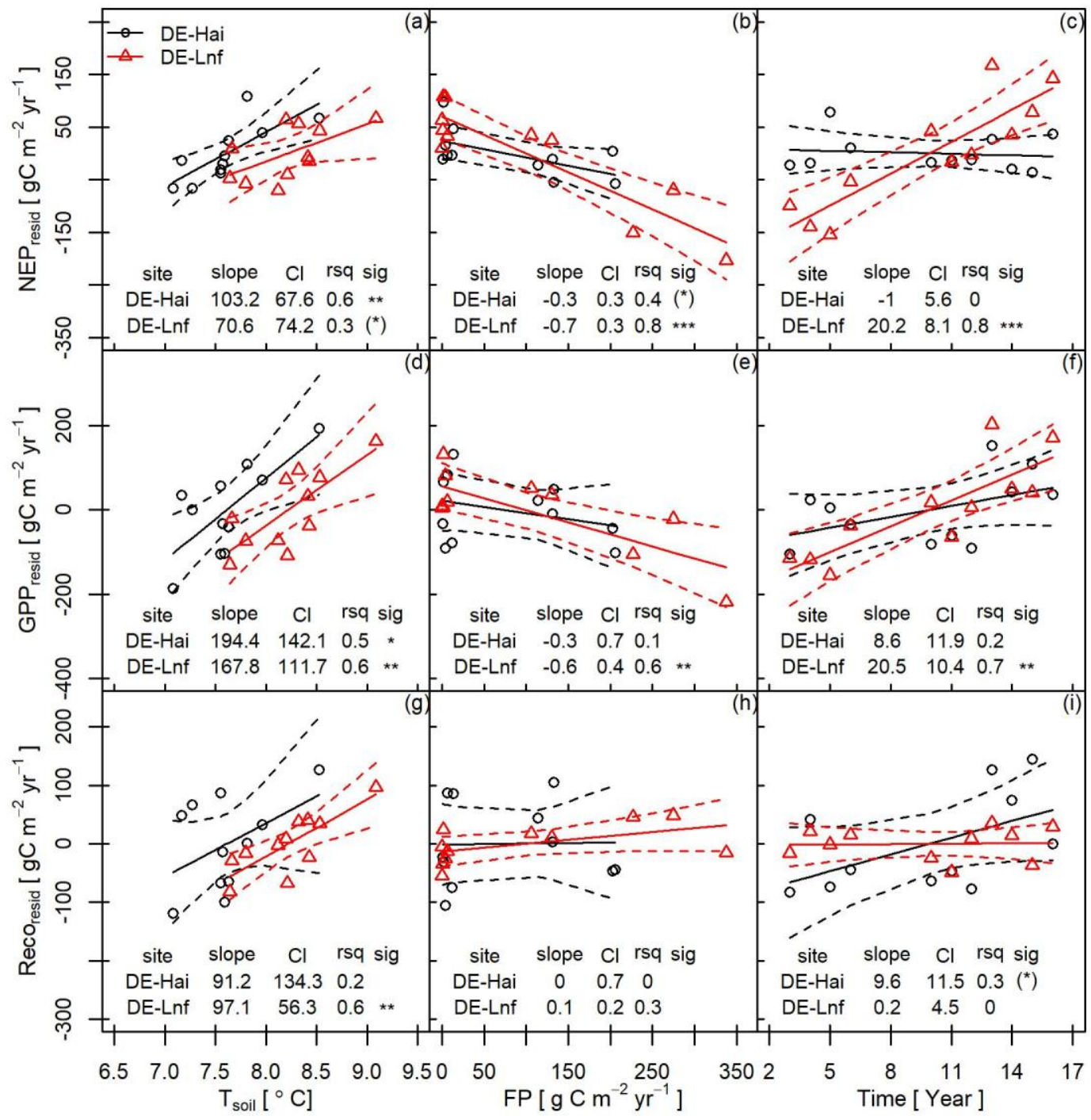

Figure 9: Simple linear regressions between residuals of different carbon fluxes after removing effect of fruit production and time ( $1^{\text {st }}$ column, $\left.a, d, g\right), T_{\text {soil }}$ and time $\left(2^{\text {nd }}\right.$ column, b, e, h) or $\mathrm{T}_{\text {soil }}$ and fruit production $\left(3^{\text {rd }}\right.$ column, $\left.\mathrm{c}, \mathrm{f}, \mathrm{i}\right)$. Here time is represented by number plus 2000 for clean graph. The solid lines represent linear regression lines and dashed lines confidence interval at $5 \%$ significance level. $* * *$ indicate statistical significance at $\mathrm{p}<0.001 ; * *$ significant at $\mathrm{p}<0.01 ; *$ significant at $\mathrm{p}<0.05$; and $(*)$ significant at $\mathrm{p}<0.1$.

Discussion

408 We observed stronger sensitivity of winter Reco to $T_{\text {soil }}$ (Figure 6) resulting in higher

1. Meteorological controls of seasonal $\mathrm{CO}_{2}$ fluxes

Reco in DE-Hai than in DE-Lnf, thus, higher winter NEP in DE-Lnf (Figure 7). Higher 
410

411

412

413

414

415

416

417

418

419

420

421

422

423

424

425 observed higher sensitivity of GPP to $\mathrm{T}_{\text {soil }}$ in DE-Lnf than in DE-Hai $(\mathrm{p}<0.1)$. This could

426 be explained by an earlier physiological activity in beech than in ash (Cole and Sheldon,

427 2017). DE-Lnf is a beech monoculture comprising mostly vital trees at their optimal age

428 (optimal regarding wood growth and fruit production) whereas DE-Hai has $28 \%$ ash trees

429 and includes many small, young, suppressed, very old, semi-dead and dead trees.

430 In summer (June - July), $\mathrm{R}_{\mathrm{g}}$ was the most important environmental factor controlling

431 carbon fluxes of both sites. DE-Lnf was a stronger sink with higher GPP and Reco

432 because it is full of optimally growing trees that may have capitalised the radiation more

433 than DE-Hai. Similarly, the stronger sensitivity of summer GPP and Reco to $\mathrm{R}_{\mathrm{g}}$ of DE- 
434 Lnf can be attributed to optimally growing trees of similar size and age that react to 435 weather conditions in same direction and magnitude.

436 August is of interest for DE-Hai where soil water availability (WAI) influences its $\mathrm{CO}_{2}$

437 fluxes. DE-Hai is more affected than DE-Lnf by water availability because of ash trees

438 that are still active when WAI drops below a critical value (e.g. 2003). Trees close their

439 stomata as the soil water availability reduces to prevent water loss (Chaves et al., 2002)

440 also decreasing photosynthesis and respiration.

2. Annual $\mathrm{CO}_{2}$ fluxes and its inter-annual variability

442 Before comparing DE-Lnf with DE-Hai, it is useful to discuss site management and

443 history. DE-Lnf is an example of a managed even-aged stand that represents one point in

444 time of a rotation period (production cycle) lasting about 120-140 years. Within the

445 production cycle, DE-Lnf represents a mature stand at its late optimum phase - with "late

446 optimum" meaning close to the end of highest timber production. If the stand were not a

447 certified seed production site, and if the eddy tower were not there, the stand would have

448 been thinned more heavily (preparatory thinning) to start the regeneration under the

449 shelter of the older trees. This means that if the site were like any other common managed

450 beech stand, then living biomass and NEP might be much smaller. For a comparison of

451 managed, even-aged forests with unmanaged forests a chronosequence of several even-

452 aged stands covering the entire production cycle would be needed. We thus note that the

453 heterogeneous stand is not being compared with the average managed beech forest in the

454 region, but rather with a particularly mature and productive stand. This must be taken into

455 account before concluding on the general impact of management on the $\mathrm{C}$ cycle.

456 Both the sites were strong carbon sinks despite one site being in an advanced stage of

457 growth with trees as old as 265 years. The ranges of annual NEP were comparable with

458 Oak Ridge forest in Tennessee, US (577 $\pm 63 \mathrm{~g} \mathrm{C} \mathrm{m}^{-2} \mathrm{yr}^{-1}$, Wilson and Baldocchi, 2001),

459 Ozarks forest in Missouri, US (479 $\pm 6563 \mathrm{~g} \mathrm{C} \mathrm{m}^{-2} \mathrm{yr}^{-1}$, Shao et al., 2014), and Oak 
460

461

462

463

464

465

466

467

468

469

470

471

472

473

474

475

476

477

478

479

480

481

482

483

484

woodland forests, UK (486 $\pm 115 \mathrm{~g} \mathrm{C} \mathrm{m}^{-2} \mathrm{yr}^{-1}$, Wilkinson et al., 2012) but slightly higher than average annual NEP for temperate forests (350 $\pm 100 \mathrm{~g} \mathrm{C} \mathrm{m}^{2} \mathrm{yr}^{-1}$, Table S5).

Average annual GPP and Reco of both sites also fell within the range average annual GPP $\left(1506 \pm 214 \mathrm{~g} \mathrm{C} \mathrm{m}^{-2} \mathrm{yr}^{-1}\right)$ and Reco $\left(1181 \pm 158 \mathrm{~g} \mathrm{C} \mathrm{m}^{-2} \mathrm{yr}^{-1}\right)$ of temperate deciduous forests.

A previous study of the same sites using seven years of data (Herbst et al., 2015) reported small but non-significant difference between the sites for NEP. However, by including four more recent years we found a significant difference in NEP between the two sites. The absolute difference in mean annual NEP $\left(98 \mathrm{~g} \mathrm{C} \mathrm{m}^{-2} \mathrm{yr}^{-1}\right)$ results from a higher mean annual GPP of $69 \mathrm{~g} \mathrm{C} \mathrm{m}^{-2} \mathrm{yr}^{-1}$ (2/3 of NEP) plus a lower mean annual Reco of $29 \mathrm{~g} \mathrm{C} \mathrm{m}^{-2}$ $\mathrm{yr}^{-1}(1 / 3$ of NEP) in DE-Lnf. The higher mean annual values of NEP in DE-Lnf is due to higher annual NEP after 2011 than DE-Hai. After 2011, significantly higher GPP and lower Reco in DE-Lnf resulted in higher NEP. The higher carbon uptake in DE-Lnf was determined by the activities during winter, spring and summer (section 1).

We observed lower coefficient of variation (CV) of annual NEP for both the sites compared to average $\mathrm{CV}$ of annual NEP of temperate forests. Average CV of annual NEP for temperate forests is $35 \%$ ( $\mathrm{sd}= \pm 100 \mathrm{~g} \mathrm{C} \mathrm{m}^{-2} \mathrm{yr}^{-1}$, Baldocchi et al., 2018 and Table S5) with the highest CV of $66 \%$ observed in the Borden forest (Froelich et al., 2015) and Sorø forest (Pilegaard et al., 2011). Interestingly, the CV of annual NEP in DE-Hai was the lowest among reported results for temperate deciduous forests and remained similar even after adding four years of data. Also, the CV of annual GPP and Reco of both sites were lower than the average for temperate deciduous forests. Like annual NEP, CV of annual GPP in DE-Hai was lowest among all the temperate deciduous broadleaved forests following the results of Musavi et al. (2017) that reported older and diverse forests had less variation in saturated gross primary productivity $\left(\mathrm{GPP}_{\text {sat }}\right)$. Between our sites, the 
managed, homogeneous forest showed a higher CV in NEP and GPP than the unmanaged, heterogeneous forest.

487

Long-term studies conducted in temperate deciduous forests have identified many factors contributing to site-specific inter-annual variation of NEP. Some studies have found that growing season length explains inter-annual variation in NEP: the Borden forest in Canada (Froelich et al., 2015), Sorø forest in Denmark (Pilegaard et al., 2011), Hesse forest (Granier et al., 2008), Morgan-Monroe State Forest in Indiana (Dragoni et al., 2011). In our case, we observed positive correlation between growing season length and NEP and GPP (Figure S4e, f and g), and at the same time positive correlation between growing season length and temperatures (Figure S3). Among $\mathrm{T}_{\text {air }}$ and $\mathrm{T}_{\text {soil, }}$, we found stronger relationship of $\mathrm{T}_{\text {soil }}$ with NEP and GPP (Figure S6 and Figure S7), this could have led to selection of $\mathrm{T}_{\text {soil }}$ in multiple linear model selection using AIC criteria. At an annual scale, we found that sensitivities of $\mathrm{T}_{\text {soil }}$ to NEP and GPP were similar based on residual analysis conducted after removing effect of fruit production and time. Other two important factors that explained annual fluxes were fruit production and time. We will discuss them separately in section 3 and 4 .

\section{Effect of fruit production on $\mathrm{CO}_{2}$ fluxes}

Fruit production (FP) was negatively correlated with NEP at both sites (Figure S8). The negative slope of NEP vs fruit production was mostly the result of a reduction of GPP in high fruit production years, i.e. photosynthesis decreased with increasing fruit production. Many studies reported that tree ring growth was reduced in years of high fruit production (e.g. Holmsgaard, 1955; Mund et al., 2010). Different mechanisms have been reported for this reduced growth in trees, including reduced photosynthetic rates in reproductive branches due to $\mathrm{N}$ or $\mathrm{P}$ depletion in those branches (Sala et al., 2012), smaller leaves (Innes, 1992), reduced leaf area (Ferretti et al., 1998), lower number of leaves during the 
mast year (Han et al., 2008) which could be due to diminished shoot growth and increased foliar bud mortality (Ishihara and Kikuzawa, 2009) as foliar buds are replaced by seeds (Innes, 1994).

It is important to note that the effect was stronger in DE-Lnf - a homogeneous forests with trees in a similar fruit-producing age class (150 -170 years) (Herbst et al., 2015). On the other hand, DE-Hai has a heterogeneous structure with different species and a wide range of tree age from 0 to 265 years. Thus, fruit production does not occur in all trees (Figure 3).

\section{Effect of time on $\mathrm{CO}_{2}$ fluxes}

Many studies report that $\mathrm{CO}_{2}$ fluxes in temperate forests have been increasing (Fernández-Martínez et al., 2017; Froelich et al., 2015; Granier et al., 2008; Pilegaard et al., 2011b, etc). A significant increasing temporal trend in $\mathrm{CO}_{2}$ uptake has also been observed in ca. 80 year-old managed beech forest in Sorø, Denmark (-23 $\mathrm{g} \mathrm{C} \mathrm{m}^{-2} \mathrm{yr}^{-1}$, Pilegaard et al., 2011), ca. 40 year-old managed beech forest in Hesse, France (-43 g C m ${ }^{2} \mathrm{yr}^{-1}$, Granier et al., 2008) and ca. 95 year-old managed maple, white oak and red oak Harvard forest in US (-16 $\mathrm{g} \mathrm{C} \mathrm{m}^{-2} \mathrm{yr}^{-1}$, Urbanski et al., 2007). We observed a similar temporal trend in NEP in DE-Lnf, a managed homogeneous forest, which was not visible when Herbst et al., (2015) reported 7 years' data. The NEP of DE-Hai was reported to be - $494 \mathrm{~g} \mathrm{C} \mathrm{m}^{-2}$ and - $490 \mathrm{~g} \mathrm{C} \mathrm{m}^{-2}$ for 2000 and 2001, respectively by Knohl et al., (2003) and the capacity remained in the same range for all 12 years described here, exhibiting no significant temporal trend. However, we observed positive trends in annual GPP and Reco at DE-Hai which might have cancelled resulting in no trend in NEP. The normal temporal trend in forest productivity is to follow a sigmoidal growth curve as individuals age. Overlaid on this, however, are the impacts of increasing atmospheric $\mathrm{CO}_{2}$ concentration, decreasing sulphur deposition (Fernández-Martínez et al., 2017), increasing nitrogen deposition, as well as management activities such as thinning. Here 
we used time as a variable because it is hard to disentangle these effects. Thus, our

537 observed temporal trend in DE-Lnf needs a careful interpretation because the trend

538 appears to reflect an increase in $\mathrm{CO}_{2}$ uptake starting from 2012 (Figure 8), and there was

539 no significant temporal trend in any of the observed meteorological variables that could

540 explain this increase (Table S1). We observed a positive trend in growing season length

541 (0.75 days per year, $\mathrm{p}<0.05)$, which explained about $19 \%$ of the variability in NEP $(\mathrm{p}=$

542 0.16) but which was not as high as reported for Hesse (Granier et al., 2008), Sorø

543 (Pilegaard et al., 2011), Borden forest (Froelich et al., 2015), and Morgan Monroe state

544 forest (Dragoni et al., 2011). As an alternate hypothesis, we note that thinning operations

545 were carried out in the main flux footprint area of DE-Lnf, and we speculate that because

546 thinning has the effect of increasing productivity in the remaining trees, this might have

547 impacted NEP subsequently. About $2319 \mathrm{~g} \mathrm{C} \mathrm{m}^{-2}$ of biomass was thinned from the

548 footprint area from 2002 to 2006 (Figure S1) and the largest thinning was carried out in

$5492005\left(998 \mathrm{~g} \mathrm{C} \mathrm{m}^{-2}\right)$. We observed higher NEP of $171 \mathrm{~g} \mathrm{C} \mathrm{m}^{-2} \mathrm{yr}^{-1}$ in the period 2010 -

5502016 compared to 2003 - 2006 (Table S3). About $1197 \mathrm{~g} \mathrm{C} \mathrm{m}^{-2}$ of additional carbon was

551 absorbed by DE-Lnf over the period of 7 years. We note that Sorø was thinned about 20

$552 \%$ every 10 years (Pilegaard et al., 2011) and Hesse was thinned every five years (Granier

553 et al., 2008), yet these authors did not report any significant effect of thinning on $\mathrm{CO}_{2}$

554 fluxes. This could be due to the effects of thinning being seen only gradually over the

555 following years as trees adjust to the new conditions, thus making the connection

556 between $\mathrm{C}$ fluxes and thinning difficult to percieve or quantify.

\section{$5572 . \quad$ Conclusions}

558 We compared two temperate deciduous forest types with similar site and meteorological

559 conditions but with different structure in terms of diameter distribution, age and species

560 composition. We found that the homogeneous forest was a higher carbon sink than the

561 heterogeneous forest due to lower respiration rates in winter and higher carbon uptake 
rates in spring and summer. $\mathrm{CO}_{2}$ uptake by the homogeneous forest has increased in recent years playing a key role in determining differences between the forests. We identified an overall time-effect but could not disentangle possible contributing factors such as increasing atmospheric $\mathrm{CO}_{2}$ concentrations or effects of silvicultural management.

In the introduction section, we put forward two hypotheses. Regarding hypothesis one, i.e. higher sensitivity of carbon fluxes of homogenous forests to environmental variables, we concluded that the homogenous forest showed a stronger sensitivity to environmental variables during spring $\left(\mathrm{T}_{\text {soil }}\right)$ and summer $\left(\mathrm{R}_{\mathrm{g}}\right)$ causing inter-annual differences between sites. At annual scale, however, the sensitivities of $\mathrm{CO}_{2}$ fluxes to environment variables are similar due to stronger control by biotic factors. In case of the second hypothesis, i.e. a higher negative sensitivity of $\mathrm{CO}_{2}$ fluxes of the homogenous forest to fruit production, we see that the NEP of the homogenous forest showed a stronger sensitivity to fruit production due to a higher negative sensitivity of GPP and higher positive sensitivity of Reco to fruit production. The relationships are weak; thus, we suggest that more data are required to confirm the hypothesis.

Even though both forests are of same average age, structures of these forests vary. This leads to different responses of the $\mathrm{CO}_{2}$ fluxes to environmental and biotic factors. Thus, it is necessary that we include structural information along with species traits (fruiting characteristics) and management activities to be able to predict the $\mathrm{CO}_{2}$ fluxes in response to future climate.

Acknowledgements

We would like to thank Erasmus Mundus Joint Doctorate Programme Forest and Nature for Society (EMJD FONASO) and German Federal Ministry of Education and Research for funding this research. We thank the administration of the Hainich National Park and the forestry district Leinefelde for the opportunity for research in their forest areas. We 
588 are also indebted to Ernst-Detlef Schulze, Olaf Kolle, Kerstin Hippler, Karl Kübler,

589 Martin Hertel, Agnes Fastnacht (Max-Planck Institute for Biogeochemistry), Peter

590 Anthoni (Karlsruhe Institute of Technology KIT, Institute of Meteorology and Climate

591 Research Atmospheric Environmental Research), Corinna Rebmann (Helmholtz Centre

592 for Environmental Research - UFZ), Frank Tiedemann, Dietmar Fellert, Heinrich

593 Kreilein, Martin Lindenberg, Lukas Siebicke (University of Göttingen) and Werner

594 Kutsch (ICOS) for their work at the Hainich and Leinefelde tower sites.

595 
597

598

599

600

601

602

603

604

605

606

607

608

609

610

611

612

613

614

615

616

617

618

619

620

621

622

623

624

625

626

627

628

629

630

631

632

633

634

635

636

637

638

639

640

641

642

Alvarez-Uria, P., Körner, C., 2007. Low temperature limits of root growth in deciduous and evergreen temperate tree species. Funct. Ecol. 21, 211-218.

https://doi.org/10.1111/j.1365-2435.2007.01231.x

Anthoni, P.M., Knohl, A., Rebmann, C., Freibauer, A., Mund, M., Ziegler, W., Kolle, O., Schulze, E.D., 2004. Forest and agricultural land-use-dependent $\mathrm{CO} 2$ exchange in Thuringia, Germany. Glob. Chang. Biol. 10, 2005-2019. https://doi.org/10.1111/j.1365-2486.2004.00863.x

Aubinet, M., Grelle, A., Ibrom, A., Rannik, Ü., Moncrieff, J., Foken, T., Kowalski, A.S., Martin, P.H., Berbigier, P., Bernhofer, C., Clement, R., Elbers, J., Granier, A., Grünwald, T., Morgenstern, K., Pilegaard, K., Rebmann, C., Snijders, W., Valentini, R., Vesala, T., 1999. Estimates of the annual net carbon and water exchange of forests: the EUROFLUX methodology. Adv. Ecol. Res. 30, 113-175. https://doi.org/10.1016/S0065-2504(08)60018-5

Baldocchi, D., Chu, H., Reichstein, M., 2018. Inter-annual variability of net and gross ecosystem carbon fluxes: A review. Agric. For. Meteorol. 249, 520-533. https://doi.org/10.1016/j.agrformet.2017.05.015

Baldocchi, D., Falge, E., Gu, L., Olson, R., Hollinger, D., Running, S., Anthoni, P., Bernhofer, C., Davis, K., Evans, R., Fuentes, J., Goldstein, A., Katul, G., Law, B., Lee, X., Malhi, Y., Meyers, T., Munger, W., Oechel, W., Paw, K.T., Pilegaard, K., Schmid, H.P., Valentini, R., Verma, S., Vesala, T., Wilson, K., Wofsy, S., Baldocchi, D., Falge, E., Gu, L., Olson, R., Hollinger, D., Running, S., Anthoni, P., Bernhofer, C., Davis, K., Evans, R., Fuentes, J., Goldstein, A., Katul, G., Law, B., Lee, X., Malhi, Y., Meyers, T., Munger, W., Oechel, W., Paw, K.T., Pilegaard, K., Schmid, H.P., Valentini, R., Verma, S., Vesala, T., Wilson, K., Wofsy, S., 2001. FLUXNET: A new tool to study the temporal and spatial variability of ecosystem-scale carbon dioxide, water vapor, and energy flux densities. Bull. Am. Meteorol. Soc. 82, 2415-2434. https://doi.org/10.1175/1520-0477(2001)082<2415:FANTTS>2.3.CO;2

Baldocchi, D., Xu, L., 2005. Carbon exchange of deciduous broadleaved forestes in temperate and Mediterranean regions, in: Griffiths, H., Jarvis, P. (Eds.), The Carbon Balance of Forest Biomes. Taylor Francis, Trowbridge, UK, pp. 187-214.

Barr, A.G., Black, T.A., Hogg, E.H., Griffis, T.J., Morgenstern, K., Kljun, N., Theede, A., Nesic, Z., 2007. Climatic controls on the carbon and water balances of a boreal aspen forest, 1994-2003. Glob. Chang. Biol. 13, 561-576. https://doi.org/10.1111/j.1365-2486.2006.01220.x

Beer, C., Reichstein, M., Tomelleri, E., Ciais, P., Jung, M., Carvalhais, N., Rodenbeck, C., Arain, M.A., Baldocchi, D., Bonan, G.B., Bondeau, A., Cescatti, A., Lasslop, G., Lindroth, A., Lomas, M., Luyssaert, S., Margolis, H., Oleson, K.W., Roupsard, O., Veenendaal, E., Viovy, N., Williams, C., Woodward, F.I., Papale, D., 2010. Terrestrial Gross Carbon Dioxide Uptake: Global Distribution and Covariation with Climate. Science (80-. ). 329, 834-838. https://doi.org/10.1126/science.1184984

Chaves, M.M., Pereira, J.S., Maroco, J., Rodrigues, M.L., Ricardo, C.P.P., Osório, M.L., Carvalho, I., Faria, T., Pinheiro, C., 2002. How plants cope with water stress in the field. Photosynthesis and growth. Ann. Bot. 89, 907-916. https://doi.org/10.1093/aob/mcf105

Chen, Z., Yu, G., Zhu, X., Wang, Q., Niu, S., Hu, Z., 2015. Covariation between gross primary production and ecosystem respiration across space and the underlying 
mechanisms: A global synthesis. Agric. For. Meteorol. 203, 180-190. https://doi.org/10.1016/j.agrformet.2015.01.012

Chu, H., Chen, J., Gottgens, J.F., Desai, A.R., Ouyang, Z., Qian, S.S., 2016. Response and biophysical regulation of carbon dioxide fluxes to climate variability and anomaly in contrasting ecosystems in northwestern Ohio, USA. Agric. For. Meteorol. 220, 5068. https://doi.org/10.1016/j.agrformet.2016.01.008

Ciais, P., Reichstein, M., Viovy, N., Granier, A., Ogée, J., Allard, V., Aubinet, M., Buchmann, N., Bernhofer, C., Carrara, A., Chevallier, F., De Noblet, N., Friend, A.D., Friedlingstein, P., Grünwald, T., Heinesch, B., Keronen, P., Knohl, A., Krinner, G., Loustau, D., Manca, G., Matteucci, G., Miglietta, F., Ourcival, J.M., Papale, D., Pilegaard, K., Rambal, S., Seufert, G., Soussana, J.F., Sanz, M.J., Schulze, E.D., Vesala, T., Valentini, R., 2005. Europe-wide reduction in primary productivity caused by the heat and drought in 2003. Nature 437, 529-533. https://doi.org/10.1038/nature03972

Cole, E.F., Sheldon, B.C., 2017. The shifting phenological landscape: Within- and between-species variation in leaf emergence in a mixed-deciduous woodland. Ecol. Evol. 7, 1135-1147. https://doi.org/10.1002/ece3.2718

Davidson, E.A., Belk, E., Boone, R.D., 1998. Soil water content and temperature as independent or confounded factors controlling soil respiration in a temperate mixed hardwood forest. Glob. Chang. Biol. 4, 217-227. https://doi.org/10.1046/j.1365-2486.1998.00128.x

Dittmar, C., Zech, W., Elling, W., 2003. Growth variations of Common beech (Fagus sylvatica L.) under different climatic and environmental conditions in Europe - A dendroecological study. For. Ecol. Manage. 173, 63-78. https://doi.org/10.1016/S0378-1127(01)00816-7

Dragoni, D., Schmid, H.P., Wayson, C.A., Potter, H., Grimmond, C.S.B., Randolph, J.C., 2011. Evidence of increased net ecosystem productivity associated with a longer vegetated season in a deciduous forest in south-central Indiana, USA. Glob. Chang. Biol. 17, 886-897. https://doi.org/10.1111/j.1365-2486.2010.02281.x

Fernández-Martínez, M., Vicca, S., Janssens, I.A., Ciais, P., Obersteiner, M., Bartrons, M., Sardans, J., Verger, A., Canadell, J.G., Chevallier, F., Wang, X., Bernhofer, C., Curtis, P.S., Gianelle, D., Grünwald, T., Heinesch, B., Ibrom, A., Knohl, A., Laurila, T., Law, B.E., Limousin, J.M., Longdoz, B., Loustau, D., Mammarella, I., Matteucci, G., Monson, R.K., Montagnani, L., Moors, E.J., Munger, J.W., Papale, D., Piao, S.L., Peñuelas, J., 2017. Atmospheric deposition, CO2, and change in the land carbon sink. Sci. Rep. 7, 1-13. https://doi.org/10.1038/s41598-017-08755-8

Ferretti, M., Baratozzi, L., Cenni, E., Cozzi, A., Savini, P., 1998. Crown transparency of beech (Fagus sylvatica L.) in the northern Apennines (Italy) - Status, changes and relationships with site characteristics and other indices of tree condition. Chemosphere 36, 1037-1042. https://doi.org/10.1016/S0045-6535(97)10168-0 Field, A.P., Miles, J., Field, Z., 2012. Discovering statistics using R. Sage.

Foken, T., Göockede, M., Mauder, M., Mahrt, L., Amiro, B., Munger, W., 2004. Post-field data quality control, in: Handbook of Micrometeorology. Kluwer Academic Publishers, Dordrecht, pp. 181-208. https://doi.org/10.1007/1-4020-2265-4_9

Froelich, N., Croft, H., Chen, J.M., Gonsamo, A., Staebler, R.M., 2015. Trends of carbon fluxes and climate over a mixed temperate-boreal transition forest in southern Ontario, Canada. Agric. For. Meteorol. 211-212, 72-84. https://doi.org/10.1016/j.agrformet.2015.05.009 
Gonzalez-Meler, M.A., Hopkins, F., Flower, C.E., Lynch, D.J., Czimczik, C., Tang, J., Subke, J.-A., 2013. Ecosystem-level controls on root-rhizosphere respiration. New Phytol. 199, 339-351. https://doi.org/10.1111/nph.12271

Granier, A., Bréda, N., Biron, P., Villette, S., 1999. A lumped water balance model to evaluate duration and intensity of drought constraints in forest stands. Ecol. Modell. 116, 269-283. https://doi.org/10.1016/S0304-3800(98)00205-1

Granier, A., Bréda, N., Longdoz, B., Gross, P., Ngao, J., 2008. Ten years of fluxes and stand growth in a young beech forest at Hesse, North-eastern France. Ann. For. Sci. 65, 704. https://doi.org/Artn 704\nDoi 10.1051/Forest:2008052

Grossiord, C., Granier, A., Ratcliffe, S., Bouriaud, O., Bruelheide, H., Checko, E., Forrester, D.I., Dawud, S.M., Finer, L., Pollastrini, M., Scherer-Lorenzen, M., Valladares, F., Bonal, D., Gessler, A., 2014. Tree diversity does not always improve resistance of forest ecosystems to drought. Proc. Natl. Acad. Sci. 111, 14812-14815. https://doi.org/10.1073/pnas.1411970111

Han, Q., Kabeya, D., lio, A., Kakubari, Y., 2008. Masting in Fagus crenata and its influence on the nitrogen content and dry mass of winter buds. Tree Physiol. 28, 1269-1276. https://doi.org/10.1093/treephys/28.8.1269

Herbst, M., Mund, M., Tamrakar, R., Knohl, A., 2015. Differences in carbon uptake and water use between a managed and an unmanaged beech forest in central Germany. For. Ecol. Manage. 355, 101-108. https://doi.org/10.1016/j.foreco.2015.05.034

Holmsgaard, E., 1955. Tree-ring analyses of Danish forest trees. Det Forstl. fors $\emptyset$ gsvæsen i Danmark XXII, 1-246.

Hommeltenberg, J., Schmid, H.P., Drösler, M., Werle, P., 2014. Can a bog drained for forestry be a stronger carbon sink than a natural bog forest? Biogeosciences 11, 3477-3493. https://doi.org/10.5194/bg-11-3477-2014

Hui, D., Luo, Y., Katul, G., 2003. Partitioning interannual variability in net ecosystem exchange between climatic variability and functional change 433-442.

Humphreys, E.R., Lafleur, P.M., 2011. Does earlier snowmelt lead to greater $\mathrm{CO}_{2}$ sequestration in two low Arctic tundra ecosystems? Geophys. Res. Lett. 38, n/an/a. https://doi.org/10.1029/2011GL047339

IGBP Terrestrial Carbon Working Group, I.T.C.W., 1998. CLIMATE: The Terrestrial Carbon Cycle: Implications for the Kyoto Protocol. Science (80-. ). 280, 1393-1394. https://doi.org/10.1126/science.280.5368.1393

Innes, J.L., 1994. The occurrence of flowering and fruiting on individual trees over 3 years and their effects on subsequent crown condition. Trees 8, 139-150. https://doi.org/10.1007/BF00196638

Innes, J.L., 1992. Observations on the condition of beech (Fagus sylvatica L.) in Britain in 1990. Forestry 65, 35-60. https://doi.org/10.1093/forestry/65.1.35

Ishihara, M.I., Kikuzawa, K., 2009. Annual and spatial variation in shoot demography associated with masting in Betula grossa: Comparison between mature trees and saplings. Ann. Bot. 104, 1195-1205. https://doi.org/10.1093/aob/mcp217

Jensen, R., Herbst, M., Friborg, T., 2017. Direct and indirect controls of the interannual variability in atmospheric $\mathrm{CO} 2$ exchange of three contrasting ecosystems in Denmark. Agric. For. Meteorol. 233, 12-31. https://doi.org/10.1016/j.agrformet.2016.10.023

Jucker, T., Bouriaud, O., Avacaritei, D., Coomes, D.A., 2014. Stabilizing effects of diversity on aboveground wood production in forest ecosystems: linking patterns and 
processes. Ecol. Lett. 17, 1560-1569. https://doi.org/10.1111/ele.12382

Kitamura, K., Nakai, Y., Suzuki, S., Ohtani, Y., Yamanoi, K., Sakamoto, T., 2012. Interannual variability of net ecosystem production for a broadleaf deciduous forest in Sapporo, northern Japan. J. For. Res. 17, 323-332. https://doi.org/10.1007/s10310-012-0335-4

Knohl, A., Schulze, E., Kolle, O., Buchmann, N., 2003. Large carbon uptake by an unmanaged 250-year-old deciduous forest in Central Germany 118, 151-167. https://doi.org/10.1016/S0168-1923(03)00115-1

Kolle, O., Rebmann, C., 2010. 10: EddySoft : documentation of a software package to acquire and process eddy covariance data. Tech. reports, Max-Planck-Institut für Biogeochem. 10.

Law, B.., Falge, E., Gu, L., Baldocchi, D.., Bakwin, P., Berbigier, P., Davis, K., Dolman, A.., Falk, M., Fuentes, J.., Goldstein, A., Granier, A., Grelle, A., Hollinger, D., Janssens, I.., Jarvis, P., Jensen, N.., Katul, G., Mahli, Y., Matteucci, G., Meyers, T., Monson, R., Munger, W., Oechel, W., Olson, R., Pilegaard, K., Paw U, K.., Thorgeirsson, H., Valentini, R., Verma, S., Vesala, T., Wilson, K., Wofsy, S., 2002. Environmental controls over carbon dioxide and water vapor exchange of terrestrial vegetation. Agric. For. Meteorol. 113, 97-120. https://doi.org/10.1016/S0168-1923(02)00104-1 Lenth, R., Love, J., 2017. Package "Ismeans" Title Least-Squares Means. https://doi.org/10.1080/00031305.1980.10483031>

Luo, Y., Keenan, T.F., Smith, M., 2015. Predictability of the terrestrial carbon cycle. Glob. Chang. Biol. 21, 1737-1751. https://doi.org/10.1111/gcb.12766

Luyssaert, S., 2014. Land management and land-cover change have impacts of similar magnitude on surface temperature. Nat. Clim. Chang. 4, 5. https://doi.org/10.1038/NCLIMATE2196

Ma, S., Baldocchi, D.D., Xu, L., Hehn, T., 2007. Inter-annual variability in carbon dioxide exchange of an oak/grass savanna and open grassland in California. Agric. For. Meteorol. 147, 157-171. https://doi.org/10.1016/j.agrformet.2007.07.008

Mund, M., 2004. Carbon pools of European beech forests (Fagus sylvatica) under different silvicultural management 189, 256.

Mund, M., Kutsch, W.L., Wirth, C., Kahl, T., Knohl, A., Skomarkova, M. V., Schulze, E.D., 2010. The influence of climate and fructification on the inter-annual variability of stem growth and net primary productivity in an old-growth, mixed beech forest. Tree Physiol. 30, 689-704. https://doi.org/10.1093/treephys/tpq027

Musavi, T., Migliavacca, M., Reichstein, M., Kattge, J., Wirth, C., Black, T.A., Janssens, I., Knohl, A., Loustau, D., Roupsard, O., Varlagin, A., Rambal, S., Cescatti, A., Gianelle, D., Kondo, H., Tamrakar, R., Mahecha, M.D., 2017. Stand age and species richness dampen interannual variation of ecosystem-level photosynthetic capacity. Nat. Ecol. Evol. 1, 1-6. https://doi.org/10.1038/s41559-016-0048

Nathans, L.L., Oswald, F.L., Nimon, K., 2012. Interpreting Multiple Linear Regression: A Guidebook of Variable Importance. Pract. Assessment, Res. Eval. 17, 1-19. https://doi.org/10.3102/00346543074004525

Novick, K.A., Oishi, A.C., Ward, E.J., Siqueira, M.B.S., Juang, J.-Y., Stoy, P.C., 2015. On the difference in the net ecosystem exchange of $\mathrm{CO}_{2}$ between deciduous and evergreen forests in the southeastern United States. Glob. Chang. Biol. 21, 827842. https://doi.org/10.1111/gcb.12723

Obeso, J.R., 2002. The costs of reproduction in plants Author. New Phytol. 155, 321-348. https://doi.org/10.1046/j.1469-8137.2002.00477.x 
Pereira, J.S., Mateus, J.A., Aires, L.M., Pita, G., Pio, C., David, J.S., Andrade, V., Banza, J., David, T.S., Paço, T.A., Rodrigues, A., 2007. Net ecosystem carbon exchange in three contrasting Mediterranean ecosystems - the effect of drought. Biogeosciences 4, 791-802. https://doi.org/10.5194/bg-4-791-2007

Pilegaard, K., Ibrom, A., Courtney, M.S., Hummelshøj, P., Jensen, N.O., 2011. Increasing net CO2 uptake by a Danish beech forest during the period from 1996 to 2009. Agric. For. Meteorol. 151, 934-946. https://doi.org/10.1016/J.AGRFORMET.2011.02.013

R Core Team, 2017. R: A Language and Environment for Statistical Computing.

Reichstein, M., Falge, E., Baldocchi, D., Papale, D., Aubinet, M., Berbigier, P., Bernhofer, C., Buchmann, N., Gilmanov, T., Granier, A., Grunwald, T., Havrahkova, K., Ilvesniemi, H., Janous, D., Knohl, A., Laurila, T., Lohila, A., Loustau, D., Matteucci, G., Meyers, T., Miglietta, F., Ourcival, J., Pumpanen, J., Rambal, S., Rotenberg, E., Sanz, M., Tenhunen, J., Seufert, G., Vaccari, F., Vesala, T., Yakir, C., Valentini, R., 2005. On the separtion of net ecosystem exchange into assimilation and ecosystem respiration: review and improved algorithm. Glob. Chang. Biol. 11, 1424-1439.

Richardson, A.D., Hollinger, D.Y., Dail, D.B., Lee, J.T., Munger, J.W., O’Keefe, J., 2009. Influence of spring phenology on seasonal and annual carbon balance in two contrasting New England forests. Tree Physiol. 29, 321-331. https://doi.org/10.1093/treephys/tpn040

Sala, A., Hopping, K., McIntire, E.J.B., Delzon, S., Crone, E.E., 2012. Masting in whitebark pine (Pinus albicaulis) depletes stored nutrients. New Phytol. 196, 189-199. https://doi.org/10.1111/j.1469-8137.2012.04257.x

Selås, V., Piovesan, G., Adams, J.M., Bernabei, M., 2002. Climatic factors controlling reproduction and growth of Norway spruce in southern Norway. Can. J. For. Res. 32, 217-225. https://doi.org/10.1139/x01-192

Shao, J., Zhou, X., He, H., Yu, G., Wang, H., Luo, Y., Chen, J., Gu, L., Li, B., 2014. Partitioning Climatic and Biotic Effects on Interannual Variability of Ecosystem Carbon Exchange in Three Ecosystems. Ecosystems 17, 1186-1201. https://doi.org/10.1007/s10021-014-9786-0

Shao, J., Zhou, X., Luo, Y., Li, B., Aurela, M., Billesbach, D., Blanken, P.D., Bracho, R., Chen, J., Fischer, M., Fu, Y., Gu, L., Han, S., He, Y., Kolb, T., Li, Y., Nagy, Z., Niu, S., Oechel, W.C., Pinter, K., Shi, P., Suyker, A., Torn, M., Varlagin, A., Wang, H., Yan, J., $\mathrm{Yu}, \mathrm{G}$., Zhang, J., 2016. Direct and indirect effects of climatic variations on the interannual variability in net ecosystem exchange across terrestrial ecosystems. Tellus B Chem. Phys. Meteorol. 68, 30575. https://doi.org/10.3402/tellusb.v68.30575

Shao, J., Zhou, X., Luo, Y., Li, B., Aurela, M., Billesbach, D., Blanken, P.D., Bracho, R., Chen, J., Fischer, M., Fu, Y., Gu, L., Han, S., He, Y., Kolb, T., Li, Y., Nagy, Z., Niu, S., Oechel, W.C., Pinter, K., Shi, P., Suyker, A., Torn, M., Varlagin, A., Wang, H., Yan, J., Yu, G., Zhang, J., 2015. Biotic and climatic controls on interannual variability in carbon fluxes across terrestrial ecosystems. Agric. For. Meteorol. 205, 11-22. https://doi.org/10.1016/j.agrformet.2015.02.007

Urbanski, S., Barford, C., Wofsy, S., Kucharik, C., Pyle, E., Budney, J., McKain, K., Fitzjarrald, D., Czikowsky, M., Munger, J.W., 2007. Factors controlling CO2 exchange on timescales from hourly to decadal at Harvard Forest. J. Geophys. Res. Biogeosciences 112, 1-25. https://doi.org/10.1029/2006JG000293

Wilkinson, M., Eaton, E.L., Broadmeadow, M.S.J., Morison, J.I.L., 2012. Inter-annual 
variation of carbon uptake by a plantation oak woodland in south-eastern England. Biogeosciences 9, 5373-5389. https://doi.org/10.5194/bg-9-5373-2012

Wilson, K.B., Baldocchi, D.D., 2001. Comparing independent estimates of carbon dioxide exchange over 5 years at a deciduous forest in the southeastern United States. J. Geophys. Res. Atmos. 106, 34167-34178. https://doi.org/Doi 10.1029/2001jd000624

Wu, C., Chen, J.M., Black, T.A., Price, D.T., Kurz, W.A., Desai, A.R., Gonsamo, A., Jassal, R.S., Gough, C.M., Bohrer, G., Dragoni, D., Herbst, M., Gielen, B., Berninger, F., Vesala, T., Mammarella, I., Pilegaard, K., Blanken, P.D., 2013. Interannual variability of net ecosystem productivity in forests is explained by carbon flux phenology in autumn. Glob. Ecol. Biogeogr. 22, 994-1006. https://doi.org/10.1111/geb.12044

Wu, C., Chen, J.M., Gonsamo, A., Price, D.T., Black, T.A., Kurz, W.A., 2012. Interannual variability of net carbon exchange is related to the lag between the end-dates of net carbon uptake and photosynthesis: Evidence from long records at two contrasting forest stands. Agric. For. Meteorol. 164, 29-38. https://doi.org/10.1016/j.agrformet.2012.05.002

Wutzler, T., Reichstein, M., Moffat, A.M., Menzer, O., Migliavacca, M., Sickel, K., Sigut, L., 2018. Title Post Processing of (Half-)Hourly Eddy-Covariance Measurements.

Yuan, W., Luo, Y., Richardson, A.D., Oren, R., Luyssaert, S., Janssens, I.A., Ceulemans, R., Zhou, X., Grünwald, T., Aubinet, M., Berhofer, C., Baldocchi, D.D., Chen, J., Dunn, A.L., Deforest, J.L., Dragoni, D., Goldstein, A.H., Moors, E., Munger, J.W., Monson, R.K., Suyker, A.E., Starr, G., Scott, R.L., Tenhunen, J., Verma, S.B., Vesala, T., Wofsy, S.T.E., 2009. Latitudinal patterns of magnitude and interannual variability in net ecosystem exchange regulated by biological and environmental variables. Glob. Chang. Biol. 15, 2905-2920. https://doi.org/10.1111/j.1365-2486.2009.01870.x 
862

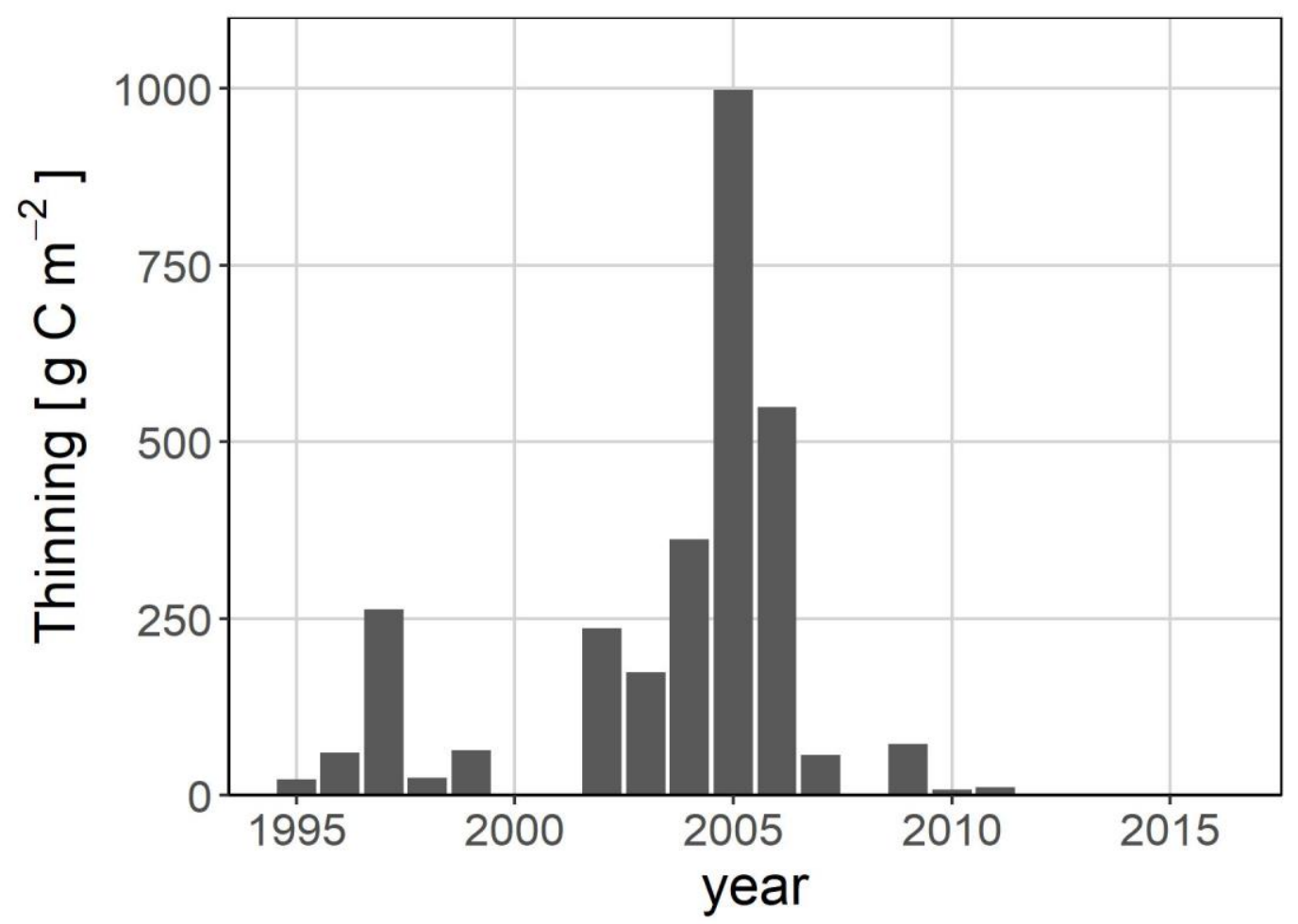

Figure S1: Annual footprint weighted thinning in eddy flux footprint area of DE-Lnf from 1995 to 2016. The highest thinning of $998 \mathrm{~g} \mathrm{C} \mathrm{m}^{-2}$ was conducted in 2005 from the footprint area.

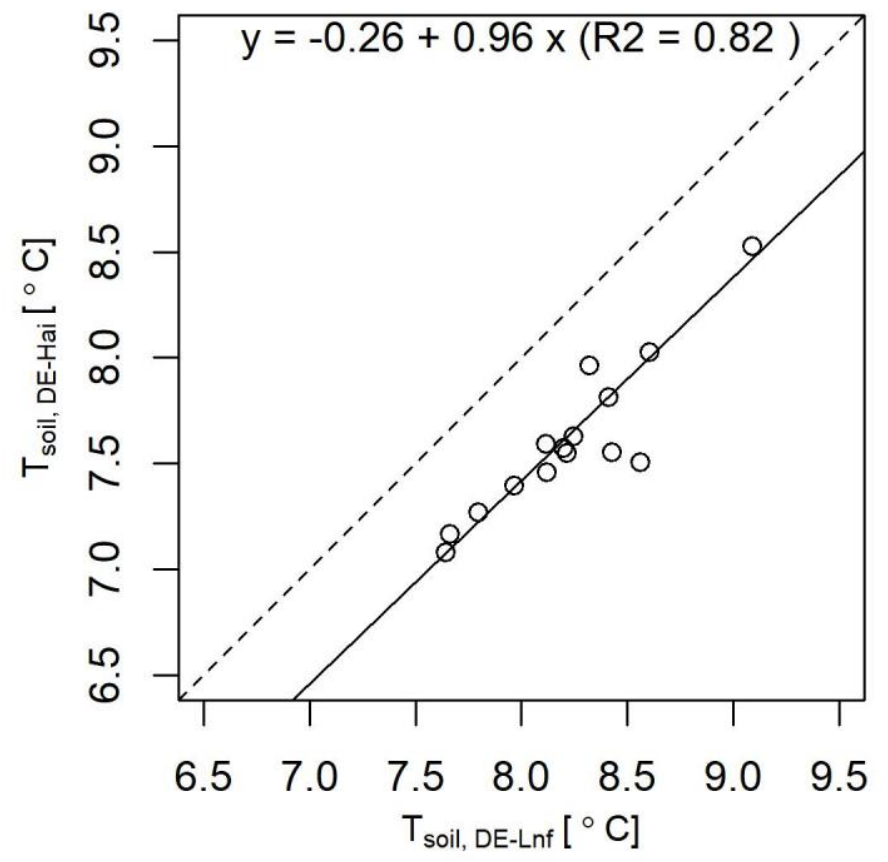

Figure S2: Linear regression between mean annual $\mathrm{T}_{\text {soil }}$ of DE-Lnf and DE-Hai. Dashed line represents a line with slope 1 . Systematic difference between sites is due to difference in measurement depths (5 vs $4 \mathrm{~cm}$ in DE-Hai and DE-Lnf, respectively). 
871 Table S1: Average Annual values (mean and sd) and the temporal trend during the study 872 period for all dependent and selected predictor variables for both sites. Units for GSS 873 (growing season start day), and GSE (growing season end day) is doy $\mathrm{yr}^{-1}$ where doy 874 indicates Julian day of the year. Trend is the temporal trend and $*$ indicates the

875 statistically significant values at 5\% significance level.

\begin{tabular}{|c|c|c|c|c|c|c|c|}
\hline \multirow[b]{2}{*}{ Variables } & \multirow[b]{2}{*}{ Units } & \multicolumn{3}{|c|}{ DE-Hai } & \multicolumn{3}{|c|}{ DE-Lnf } \\
\hline & & mean & sd & trend & mean & $\mathrm{sd}$ & trend \\
\hline $\mathrm{R}_{\mathrm{g}}$ & $\mathrm{W} \mathrm{m} \mathrm{m}^{-2}$ & 122 & 6.5 & 0.18 & 124.0 & 7.2 & 0.62 \\
\hline $\mathrm{T}_{\text {air }}$ & ${ }^{\circ} \mathrm{C} \mathrm{yr}^{-1}$ & 8.34 & 0.72 & 0.03 & 8.30 & 0.70 & 0.05 \\
\hline $\mathrm{T}_{\text {soil }}$ & ${ }^{\circ} \mathrm{C} \mathrm{yr}^{-1}$ & 7.61 & 0.36 & 0.01 & 8.23 & 0.38 & 0.02 \\
\hline VPD & $\mathrm{hPa} \mathrm{yr} \mathrm{r}^{-1}$ & 3.45 & 0.56 & 0.02 & 3.28 & 0.48 & 0 \\
\hline Rain & $\mathrm{mm} \mathrm{yr}^{-1}$ & 744 & 152 & -6.76 & 601 & 154 & -9.12 \\
\hline WAI & $\mathrm{yr}^{-1}$ & 0.86 & 0.09 & -0.01 & 0.84 & 0.1 & 0 \\
\hline NEP & $\mathrm{g} \mathrm{C} \mathrm{m}^{-2} \mathrm{yr}^{-1}$ & 487 & 57.8 & -3.14 & 585 & 144 & $21.8 *$ \\
\hline GPP & $\mathrm{g} \mathrm{C} \mathrm{m}^{-2} \mathrm{yr}^{-1}$ & 1558 & 118 & 4.25 & 1627 & 164 & $25.5 *$ \\
\hline$\underline{\text { Reco }}$ & $\mathrm{g} \mathrm{C} \mathrm{m}^{-2} \mathrm{yr}^{-1}$ & 1071 & 96 & 0.28 & 1042 & 60 & 0.08 \\
\hline GSS & doy $\mathrm{yr}^{-1}$ & 125 & 7 & -0.42 & 121 & 5 & -0.29 \\
\hline GSE & doy $\mathrm{yr}^{-1}$ & 289 & 4 & -0.35 & 288 & 5 & 0.45 \\
\hline GSL & day $\mathrm{yr}^{-1}$ & 164 & 7 & 0.07 & 168 & 6 & $0.75 *$ \\
\hline $\begin{array}{l}\text { Fruit } \\
\text { production }\end{array}$ & $\mathrm{g} \mathrm{C} \mathrm{m}^{-2} \mathrm{yr}^{-1}$ & 73.2 & 77.9 & 4.53 & 91.2 & 113.1 & 5.43 \\
\hline
\end{tabular}

878 Table S2: Growing season start day (GSS), end day (GSE) and length (GSL) for DE-Hai

879 and DE-Lnf during the study period.

\begin{tabular}{lllllll}
\hline \multirow{2}{*}{ Year } & DE-Hai & \multicolumn{5}{c}{ DE-Lnf } \\
\cline { 2 - 7 } & GSS (doy) & GSE (doy) & GSL (days) & GSS (doy) & GSE (doy) & GSL (days) \\
\hline 2003 & 125 & 292 & 167 & 123 & 290 & 167 \\
2004 & 123 & 288 & 165 & 121 & 281 & 160 \\
2005 & 125 & 293 & 168 & 122 & 291 & 169 \\
2006 & 127 & 294 & 167 & 126 & 294 & 168 \\
2010 & 134 & 283 & 149 & 123 & 283 & 160 \\
2011 & 117 & 288 & 171 & 114 & 285 & 171 \\
2012 & 129 & 289 & 160 & 124 & 290 & 166 \\
2013 & 131 & 288 & 157 & 130 & 292 & 162 \\
2014 & 111 & 284 & 173 & 112 & 288 & 176 \\
2015 & 114 & 284 & 170 & 117 & 293 & 176 \\
2016 & 130 & 292 & 162 & 117 & 292 & 175 \\
\hline Average & 125 & 289 & 164 & 121 & 289 & 168 \\
Sd & 7 & 4 & 7 & 5 & 4 & 6 \\
\hline
\end{tabular}




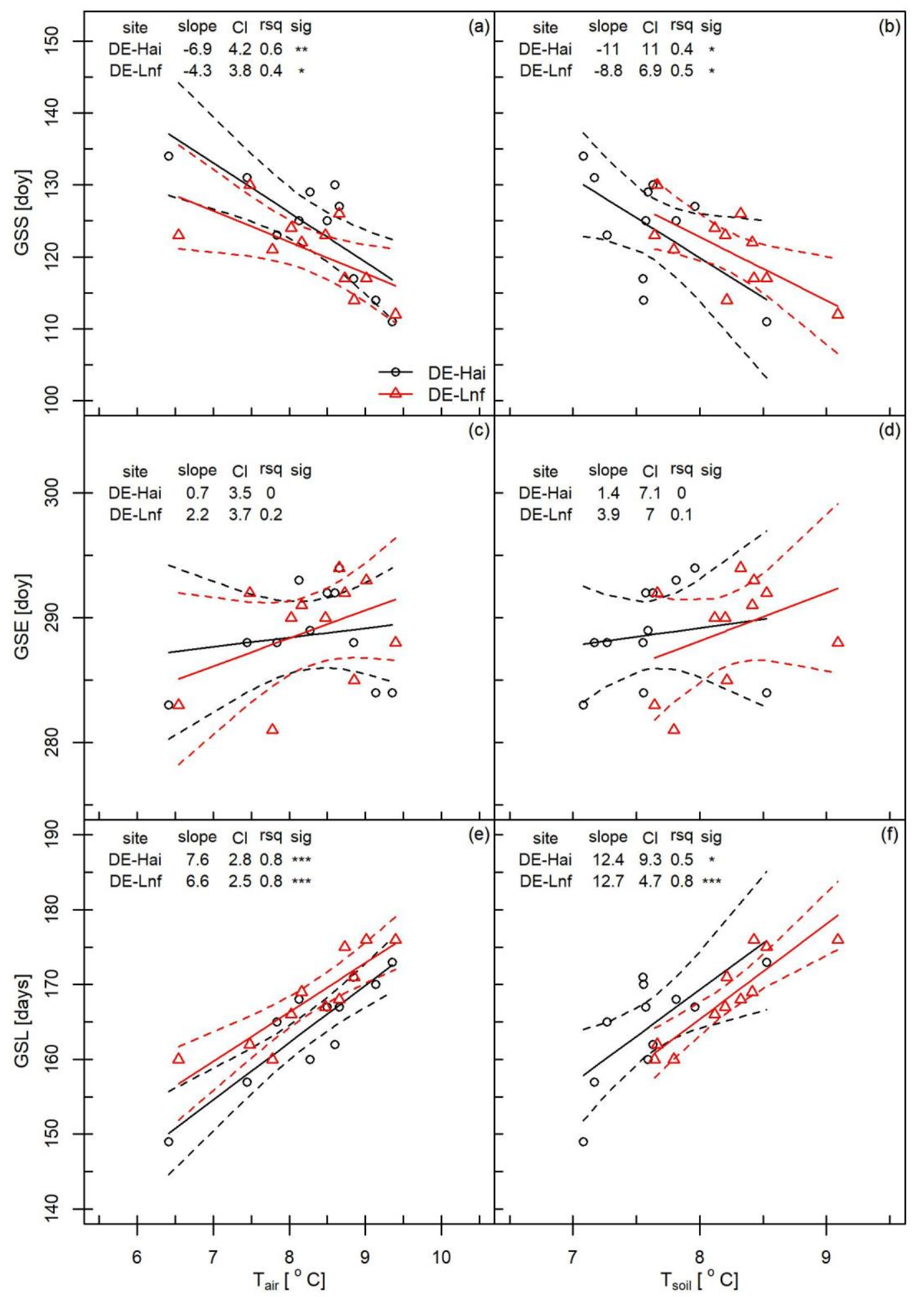

Figure S3: Relationship between $\mathrm{T}_{\text {air }}$ and $\mathrm{T}_{\text {soil }}$ with growing season matrix. GSS is growing season start day indicated by day of the year (doy), GSE is growing season end day indicated by day of the year (doy) and GSL is growing season length indicated by number of days. The solid lines represent linear regression lines and dashed lines its confidence interval at $5 \%$ significance level. $* * *$ indicate statistical significance at $\mathrm{p}<$ 0.001 ; ** significant at $\mathrm{p}<0.01 ; *$ significant at $\mathrm{p}<0.05$; and $(*)$ significant at $\mathrm{p}<0.1$. 


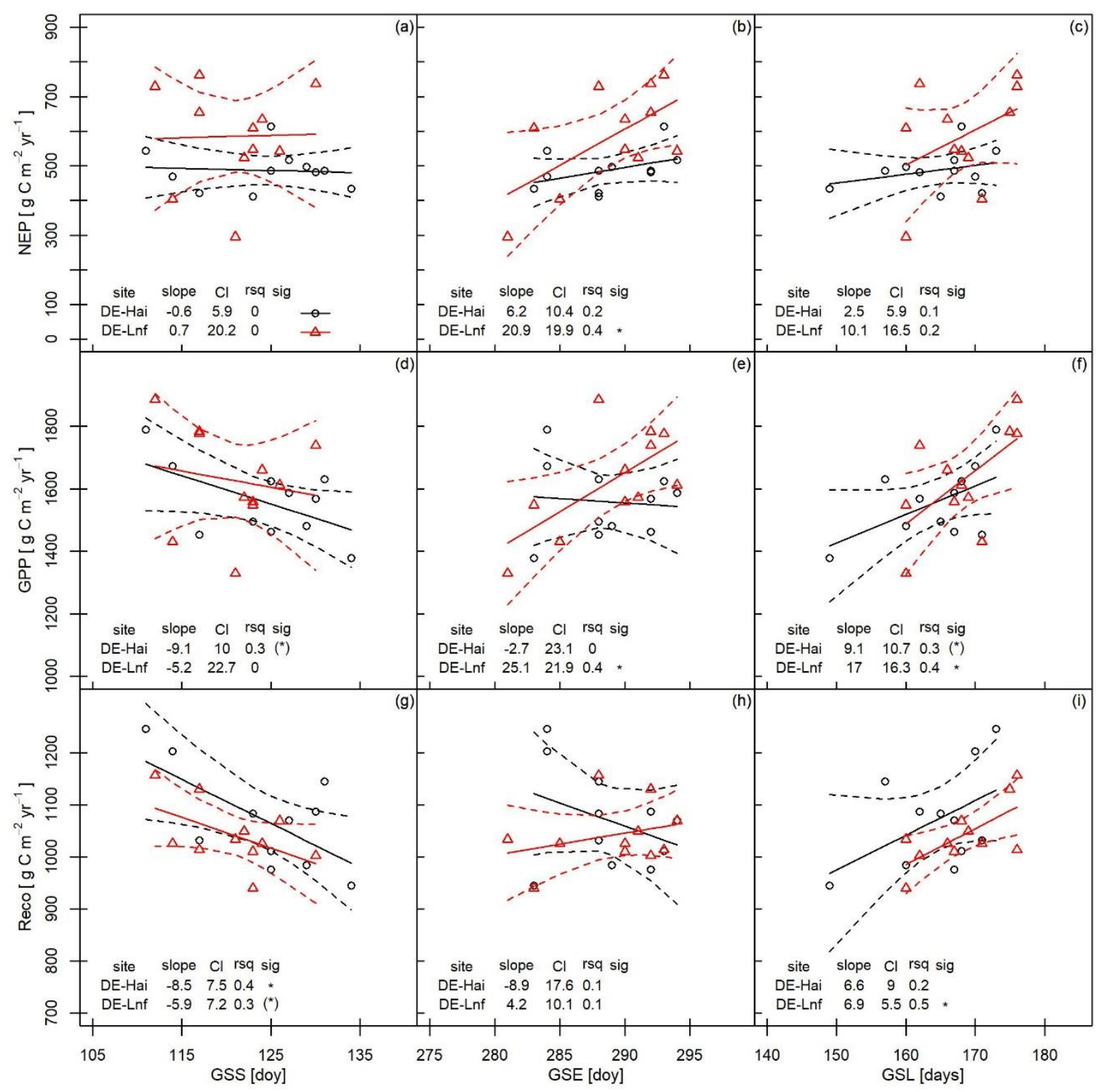

887

Figure S4: Simple linear regression between NEP, GPP and Reco with growing season start day (GSS), growing season end day (GSE) and growing season length day (GSL). The solid lines represent linear regression lines and dashed lines confidence interval at $5 \%$ significance level. $* * *$ indicate statistical significance at $\mathrm{p}<0.001 ; * *$ significant at $\mathrm{p}$ $<0.01$; $*$ significant at $\mathrm{p}<0.05$; and $(*)$ significant at $\mathrm{p}<0.1$.

Table S3: Mean annual fluxes for two periods (2003-2006 and 2010-2016) and differences between two sites. Differences between sites were tested using paired t-test.

\begin{tabular}{ccccc}
\hline period & Flux & $\begin{array}{c}\text { DE-Hai (mean } \pm \mathrm{sd}) \\
{\left[\mathrm{g} \mathrm{C} \mathrm{m}^{-2} \mathrm{yr}^{-1}\right]}\end{array}$ & $\begin{array}{c}\text { DE-Lnf (mean } \pm \mathrm{sd}) \\
{\left[\mathrm{g} \mathrm{C} \mathrm{m}^{-2} \mathrm{yr}^{-1}\right]}\end{array}$ & $\begin{array}{c}\text { Diff } \\
{\left[\mathrm{g} \mathrm{C} \mathrm{m}^{-2} \mathrm{yr}^{-1}\right]}\end{array}$ \\
\hline \multirow{3}{*}{$2003-2006$} & NEP & $506 \pm 84$ & $476 \pm 122$ & 30 \\
& GPP & $1542 \pm 76$ & $1517 \pm 128$ & 25 \\
& Reco & $1035 \pm 50$ & $1040 \pm 25$ & 2 \\
\hline \multirow{3}{*}{$2010-2016$} & NEP & $476 \pm 41$ & $647 \pm 121$ & $171^{* *}$ \\
& GPP & $1568 \pm 142$ & $1689 \pm 156$ & $121^{* *}$ \\
& Reco & $1092 \pm 112$ & $1042 \pm 76$ & -50 \\
\hline
\end{tabular}

Table S4: Difference between the two sites with respect to slopes between each of the three significant driving variables $\left(\mathrm{T}_{\text {soil }}, \mathrm{FP}\right.$, time) and the three flux quantities (NEP, 
GPP, Reco) in terms of the residual variance remaining after the effects of the other two 899 driving variables (e.g. FP and time, in the case of $\mathrm{T}_{\text {soil }}$ ) have been removed.

\begin{tabular}{llrr}
\hline $\mathrm{CO}_{2}$ flux & Variable & $\begin{array}{r}\text { Slope difference } \\
\text { (DE-Hai }- \text { DE-Lnf) }\end{array}$ & SE \\
\hline NEP & $\mathrm{T}_{\text {soil }}$ & 32.6 & 44.5 \\
GPP & $\mathrm{T}_{\text {soil }}$ & 26.6 & 79.6 \\
Reco & $\mathrm{T}_{\text {soil }}$ & -5.9 & 63.4 \\
\hline NEP & FP & $0.4 *$ & 0.2 \\
GPP & FP & 0.3 & 0.3 \\
Reco & FP & -0.1 & 0.3 \\
NEP & Time & $-21.2^{* *}$ & 4.3 \\
GPP & Time & $-11.9(*)$ & 7.0 \\
Reco & Time & $9.3(*)$ & 5.5 \\
\hline S
\end{tabular}

Slope difference indicates the difference between two sites with respect to slopes between each of the three significant driving variables ( $\mathrm{T}_{\text {soil }}, \mathrm{FP}$, time) and the three flux quantities (NEP, GPP, Reco) in terms of the residual variance remaining after the effects of the other two driving variables (e.g. FP and time, in the case of $\mathrm{T}_{\text {soil }}$ ) have been removed. $\mathrm{SE}$ is the standard error of that difference. $* * *$ indicate statistical significance at $\mathrm{p}<0.001$; ** significant at $\mathrm{p}<0.01$; * significant at $\mathrm{p}<0.05$; and $(*)$ significant at $\mathrm{p}<0.1$.

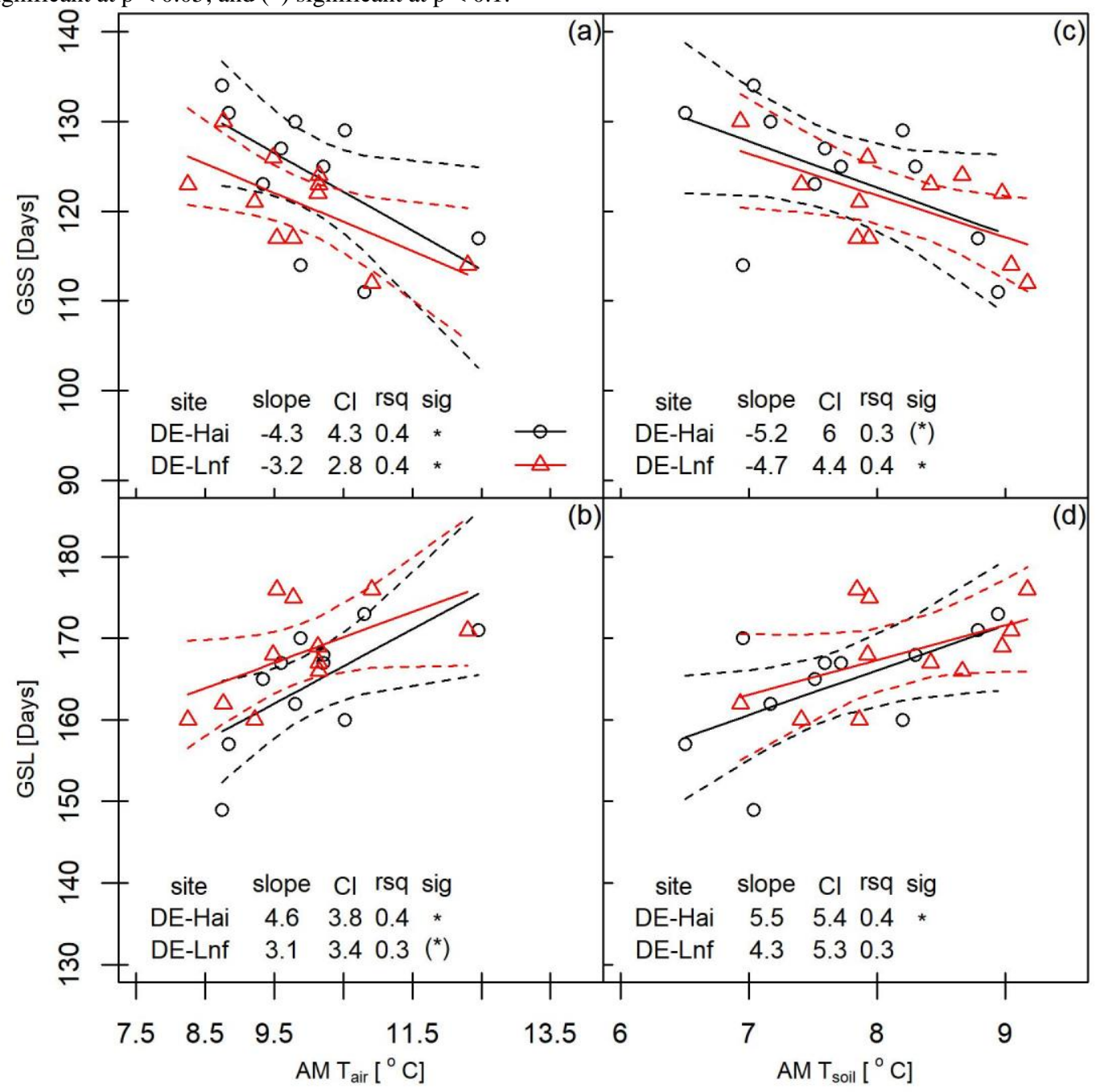

Figure S5: Relationship of growing season start day (GSS) and growing season length (GSL) with spring air (AM $\left.\mathrm{T}_{\text {air }}\right)$ and soil temperature (AM $\left.\mathrm{T}_{\text {soil }}\right)$. The solid lines represent linear regressions and dotted lines $95 \%$ confidence interval. *** indicates statistical significance at $\mathrm{p}<0.001 ; * *$ significant at $\mathrm{p}<0.01 ; *$ significant at $\mathrm{p}<0.05$; and $(*)$ significant at $\mathrm{p}<0.1$. 

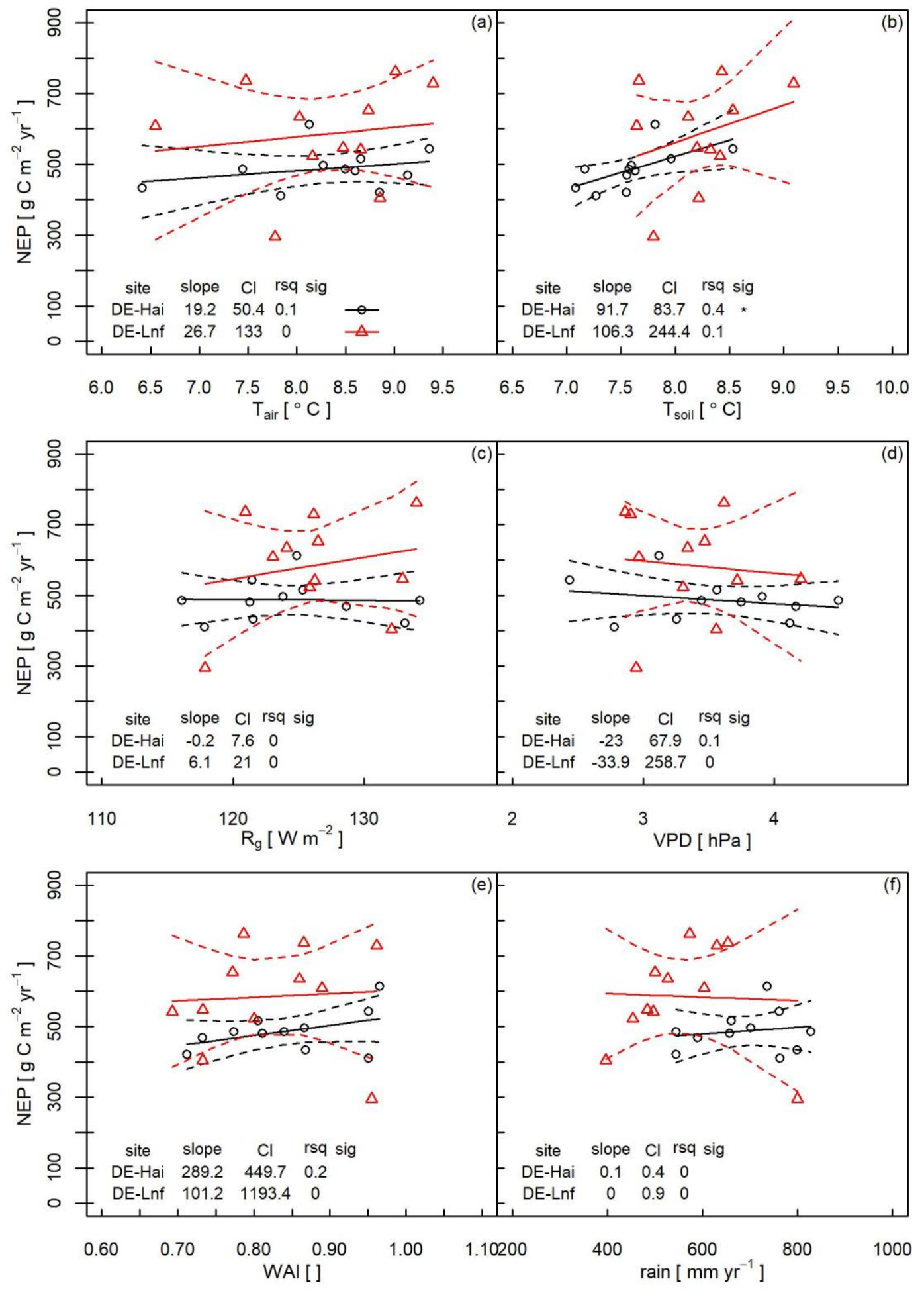

Figure S6: Regression between annual NEP and annual mean of meteorological variables (except for rain which was summed). The solid lines represent linear regressions and dotted lines $95 \%$ confidence interval. $* * *$ indicates statistical significance at $p<0.001$; $* *$ significant at $\mathrm{p}<0.01 ; *$ significant at $\mathrm{p}<0.05$; and $(*)$ significant at $\mathrm{p}<0.1$. 

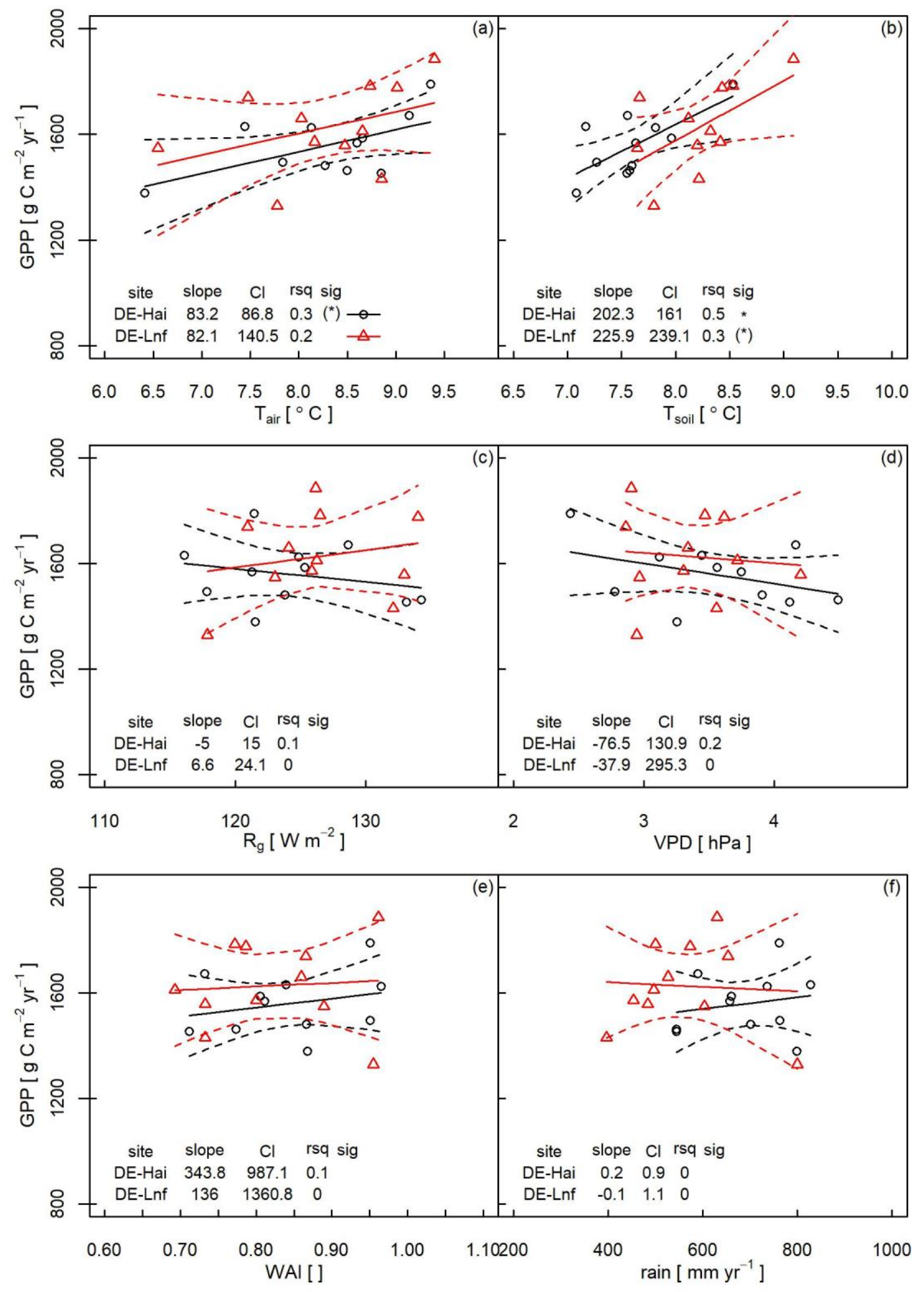

Figure S7: Regression between annual GPP and annual mean of meteorological variables (except for rain which was summed). The solid lines represent linear regressions and dotted lines $95 \%$ confidence interval. $* * *$ indicates statistical significance at $\mathrm{p}<0.001$; $* *$ significant at $\mathrm{p}<0.01 ; *$ significant at $\mathrm{p}<0.05$; and $\left.{ }^{*}\right)$ significant at $\mathrm{p}<0.1$. 


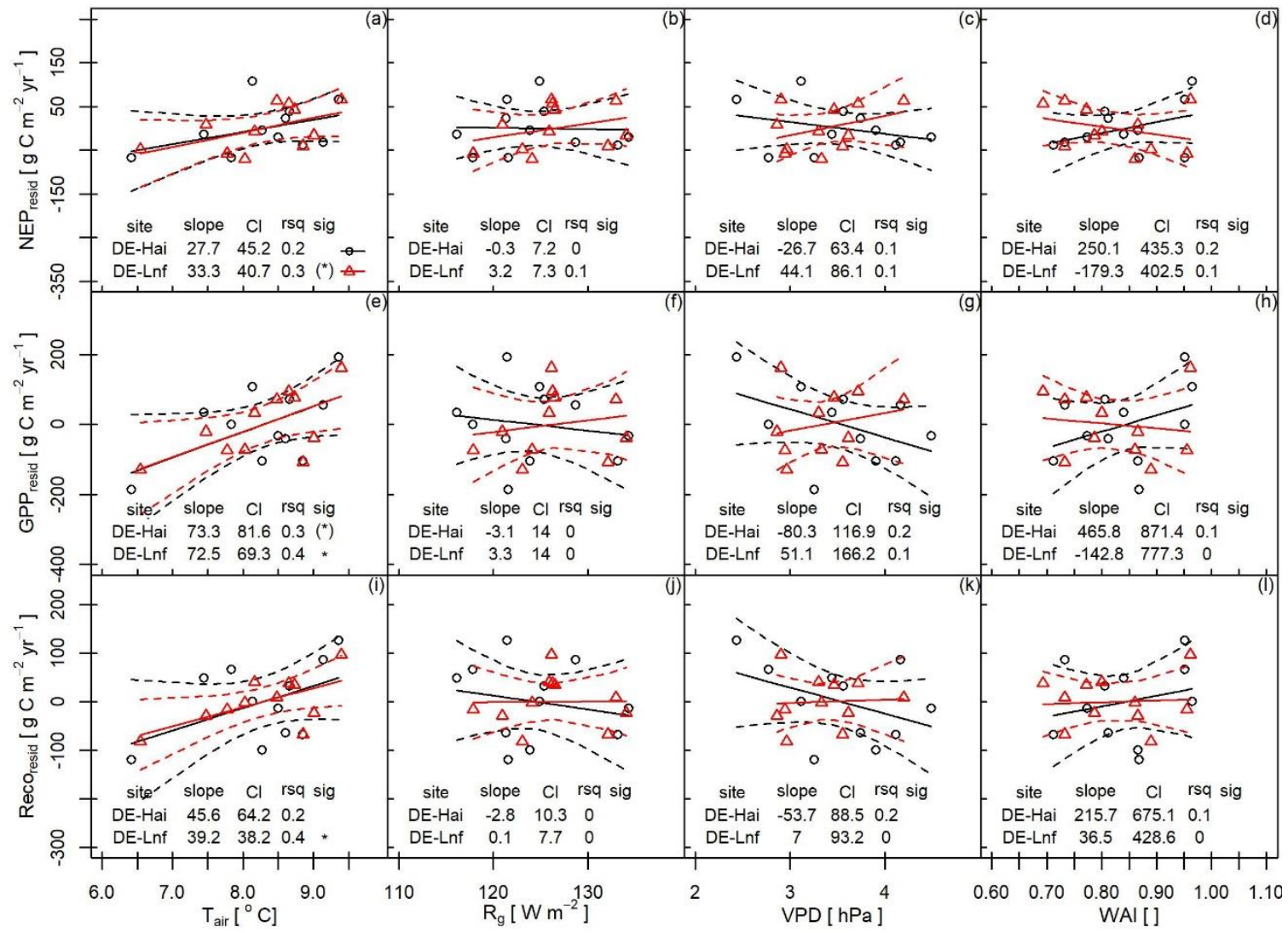

Figure S8: Linear regression between residual of NEP, GPP and Reco after removing the effect of time and fruit production (FP). CI is $95 \%$ confidence interval of slope and rsq the coefficient of determination of linear regression, and sig its significance. The solid lines represent linear regression lines and dashed lines confidence interval at $5 \%$ significance level. $* * *$ indicate statistical significance at $\mathrm{p}<0.001 ; * *$ significant at $\mathrm{p}<$ $0.01 ; *$ significant at $\mathrm{p}<0.05$; and $\left(^{*}\right)$ significant at $\mathrm{p}<0.1$. 
Table S5: Temperate broad-leaved deciduous forests with long term eddy covariance measurements. The table was modified after Baldocchi et al.

929 (2018). CV is coefficient of variation (standard deviation divided by mean).

\begin{tabular}{|c|c|c|c|c|c|c|c|c|c|c|c|c|}
\hline \multirow[b]{2}{*}{ Site } & \multirow[b]{2}{*}{ Country } & \multirow[b]{2}{*}{$\begin{array}{l}\mathbf{n} \\
--\end{array}$} & \multicolumn{3}{|c|}{ NEP } & \multicolumn{3}{|c|}{ GPP } & \multicolumn{3}{|c|}{ Reco } & \multirow[b]{2}{*}{ Reference } \\
\hline & & & 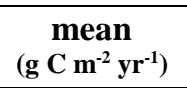 & $\begin{array}{c}\mathbf{s d} \\
\left(\mathrm{g} \mathrm{C}^{-2} \mathbf{y r}^{-1}\right)\end{array}$ & $\begin{array}{c}\text { CV } \\
--\end{array}$ & $\underset{\left(\mathrm{g} \mathrm{C} \mathrm{m}^{-2} \mathbf{y r}^{-1}\right)}{\operatorname{mean}}$ & $\begin{array}{c}\mathbf{s d} \\
\left(\mathrm{g} \mathrm{C}^{-2} \mathbf{y r}^{-1}\right)\end{array}$ & $\begin{array}{c}\text { CV } \\
--\end{array}$ & 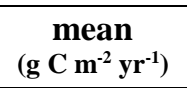 & $\begin{array}{c}\mathbf{s d} \\
\left(\mathrm{g} \mathrm{C}^{-2} \mathbf{y r}^{-1}\right)\end{array}$ & $\begin{array}{c}\mathrm{CV} \\
--\end{array}$ & \\
\hline Borden & Canada-Ontario & 18 & 177 & 116 & 0.66 & 1373 & 164 & 0.12 & 1196 & 188 & 0.16 & $\begin{array}{l}\text { Froelich et al. } \\
\text { (2015) }\end{array}$ \\
\hline Soroe & Denmark & 13 & 156 & 103 & 0.66 & 1727 & 136 & 0.08 & 1570 & 97 & 0.06 & $\begin{array}{l}\text { Pilegaard et al. } \\
\text { (2011) }\end{array}$ \\
\hline Hesse & France & 10 & 386 & 171 & 0.44 & 1397 & 192 & 0.14 & 1011 & 137 & 0.14 & $\begin{array}{l}\text { Granier et al. } \\
(2008)\end{array}$ \\
\hline Takayama & Japan & 9 & 237 & 98 & 0.41 & 1110 & 409 & 0.37 & 829 & 264 & 0.32 & \\
\hline $\begin{array}{l}\text { Straights } \\
\text { Inclosure }\end{array}$ & United Kingdom & 12 & 486 & 115 & 0.24 & 1993 & 275 & 0.14 & 1548 & 192 & 0.12 & $\begin{array}{l}\text { Wilkinson et al. } \\
\text { (2012) }\end{array}$ \\
\hline Morgan-Monroe & US-Indiana & 13 & 351 & 81 & 0.23 & 1452 & 118 & 0.08 & 1098 & 82 & 0.07 & $\begin{array}{l}\text { Sulman et al. } \\
\text { (2016) }\end{array}$ \\
\hline $\begin{array}{l}\text { Harvard Forest, } \\
\text { Petersham }\end{array}$ & $\begin{array}{l}\text { US- } \\
\text { Massachusetts }\end{array}$ & 13 & 245 & 100 & 0.41 & 1400 & 164 & 0.12 & 1153 & 105 & 0.09 & $\begin{array}{l}\text { Urbanski et al. } \\
\text { (2007) }\end{array}$ \\
\hline Ozarks & US-Missouri & 5 & 479 & 65 & 0.14 & 1125 & 164 & 0.15 & 646 & 121 & 0.19 & Shao et al. (2014) \\
\hline $\begin{array}{l}\text { Duke Forest, } \\
\text { Durham }\end{array}$ & $\begin{array}{l}\text { US-North } \\
\text { Carolina }\end{array}$ & 8 & 402 & 96 & 0.24 & 1982 & 300 & 0.15 & 1580 & 237 & 0.15 & $\begin{array}{l}\text { Novick et al. } \\
\text { (2015) }\end{array}$ \\
\hline Oak Ridge & US-Tennessee & 5 & 577 & 63 & 0.11 & $\mathrm{Na}$ & $\mathrm{Na}$ & $\mathrm{Na}$ & $\mathrm{Na}$ & $\mathrm{Na}$ & $\mathrm{Na}$ & $\begin{array}{l}\text { Wilson and } \\
\text { Baldocchi (2001) }\end{array}$ \\
\hline Average & & & 350 & 100 & 0.35 & 1506 & 214 & 0.15 & 1181 & 158 & 0.14 & \\
\hline
\end{tabular}

